Volume 61

\title{
The Federal Employers' Liability Act: Sense and Nonsense about Causation
}

Michael D. Green

Follow this and additional works at: https://via.library.depaul.edu/law-review

\section{Recommended Citation}

Michael D. Green, The Federal Employers' Liability Act: Sense and Nonsense about Causation, 61 DePaul L. Rev. 503 (2012)

Available at: https://via.library.depaul.edu/law-review/vol61/iss2/9

This Article is brought to you for free and open access by the College of Law at Digital Commons@DePaul. It has been accepted for inclusion in DePaul Law Review by an authorized editor of Digital Commons@DePaul. For more information, please contact digitalservices@depaul.edu. 


\title{
THE FEDERAL EMPLOYERS' LIABILITY ACT: SENSE AND NONSENSE ABOUT CAUSATION
}

\author{
Michael D. Green*
}

\section{INTRODUCTION}

\section{A. Bob Rabin}

Bob Rabin is an icon on the modern academic tort scene. He has, for over forty years, illuminated this area for legions of students, lawyers, judges, and academics. Bob's rigor, curiosity, balance, and plain prose make his work a pleasure to read. But his insight-making connections that elude the rest of us, teasing from historical evidence new understanding-is what makes his work so wonderful and educational. I learned torts at Bob's feet-his casebook was the one that I chose for the first torts class I taught, and I continue to use it over thirty years later. ${ }^{1}$

While I have admired Bob's academic work for a long time, I have been privileged over the past ten years to work closely with him in preparing two editions of his torts casebook. ${ }^{2}$ That experience has afforded an opportunity to observe a very different dimension of Bob Rabin, one that has deepened my respect for him and produced a strong affection. To paraphrase Spike Lee, he is maniacal about doing the right thing and assuring, no matter how much work it takes, that his work product has integrity, heft, and his full commitment. There is no fluff in Bob's professional work.

I do not want to stop there, though. Bob is warm, generous, and über reliable. He has a wonderful sense of humor, and his distaste for pedantry and pretension dovetails his own humility and lack of affect. $\mathrm{He}$ is, in short, the ideal collaborator, and I consider myself most fortunate to have had the opportunity to work with him over the past decade.

Bob has never limited his academic interest to tort law. He has explored alternatives to torts and written about virtually all of the

* Williams Professor of Law, Wake Forest University.

1. Marc A. Franklin, Robert L. Rabin \& Michael D. Green, Tort Law and Alterna. TIVES (9th ed. 2011).

2. With his typical graciousness (and nit-picking attention to detail), Bob corrected me to point out that it was now our casebook. 
targeted compensation schemes adopted in the modern era. ${ }^{3}$ The title of his casebook, Tort Law and Alternatives, reflects Bob's engagement with other mechanisms for addressing accidental injuries. Thus, it seemed appropriate for this Festschrift to address a compensation scheme that so far has eluded Bob's gaze: the Federal Employers' Liability Act (FELA). I am pleased that I managed to get to it before Bob, with his penchant for searching inquiry into alternatives and the preemptive wisdom he brings to bear on his subjects, turned to it.

\section{B. The Federal Employers' Liability Act}

I have for a number of years been vaguely aware of cases that confronted and often struggled with the Supreme Court's decision in Rogers v. Missouri Pacific Railroad Co. There, the Court declared that the FELA required only "that employer negligence played any part, even the slightest, in producing the injury." 4 This effort to honor Bob seemed like the perfect opportunity to explore the FELA, Rogers, and whether this statute is simply a statutory wrapping for common law torts or, alternatively, a compensation system in tort clothing that provides an alternative to tort law. That question, it turns out, is reflected in the modern controversy over Rogers and the causal relation required for an injured railroad worker to recover from her employer for occupational injury.

Although I did not appreciate it when I decided to pursue this topic, the literature on the FELA has ignored the troubling questions raised by Rogers and the struggle to make sense of it. Much of the sparse academic commentary about the FELA has addressed the question of whether it should be replaced with some form of workers' compensation. ${ }^{5}$ The only article that approaches FELA causation is one written

3. Examples include the Black Lung Benefits Act, see 30 U.S.C. $\$ \S 901-945$ (2006); the National Childhood Vaccine Injury Act of 1986, see 42 U.S.C. $\$ \S 300 \mathrm{a}-1$ to -34 (2006); the Swine Flu Vaccine Act, see 42 U.S.C. \$247b(j)-(1) (1976) (repealed 1978); and the September 11th Victim Compensation Fund of 2001, see 49 U.S.C. $\$ 40101$ (2000 \& Supp. IV 2004). Bob's broadest treatment of compensation systems is Robert L. Rabin, The Renaissance of Accident Law Plans Revisited, 64 MD. L. Rev. 699 (2005). For further reading, see Robert L. Rabin, Administrative Compensation Schemes, in II Reporters' Study, ENTERPRise Responsibility for Personal InJury 441 (1991); Robert L. Rabin \& Suzanne A. Bratis, Financial Compensation for Victims of Catastrophes: United States, in Financial Compensation for Victims of Catastrophes: A Comparative Legal Approach 303 (M. Faure \& T. Hartlief eds., 2006); Robert L. Rabin \& Stephen D. Sugarman, The Case for Specially Compensating the Victims of Terrorist Acts: An Assessment, 35 Hofstra L. Rev. 901 (2007); Robert L. Rabin, The Vaccine No-Fault Act: An Overview, 8 Ind. Health L. Rev. 267 (2011).

4. Rogers v. Mo. Pac. R.R., 352 U.S. 500, 506 (1957).

5. See, e.g., Thomas E. Baker, Why Congress Should Repeal the Federal Employers' Liability Act of 1908, 29 HARV. J. ON Legis. 79, 81-82 (1992). Several stakeholders have written selfinterested assessments of the statute and about whether it should be replaced. See Sidney A. 
roughly forty-five years ago and that dealt with whether the causal standard for plaintiff's contributory negligence should be the same as the one for defendant's negligence. ${ }^{6}$

The FELA was enacted over a century ago at the same time that several states were actively considering replacing tort law with workers' compensation systems. ${ }^{7}$ The history of workers' compensation reform has been repeatedly told, ${ }^{8}$ but the history of FELA is less well known. Some, including me, have understood the FELA as necessary because of federalism difficulties states would have covering employees involved in interstate railroading, but that is not the case. ${ }^{9}$ The FELA, rather, is a historical anomaly, still in operation today largely due to legislative ennui and entrenched interest groups. ${ }^{10}$

The industrial revolution produced a heavy toll on the labor that fueled it, ${ }^{11}$ and tort law was quite unsympathetic to injured employ-

Alderman, What the New Supreme Court Has Done to the Old Law of Negligence, 18 LAw \& Contemp. Probs. 110 (1953); Melvin L. Griffith, The Vindication of a National Public Policy Under the Federal Employers' Liability Act, 18 LAw \& Contemp. ProBs. 160, 162-66 (1953); Arnold I. Havens \& Anthony A. Anderson, The Federal Employers' Liability Act: A Compensation System in Urgent Need of Reform, 34 FED. B. News \& J. 310, 310-12 (1987); Clarence A. Miller, The Quest for a Federal Workmen's Compensation Law for Railroad Employees, 18 LAw \& Contemp. Probs. 188 (1953); Jerome Pollack, The Crisis in Work Injury Compensation on and off the Railroads, 18 LAw \& ConTEMP. ProBs. 296 (1953).

6. See Charles H. Traeger, III, Legal Cause, Proximate Cause, and Comparative Negligence in the FELA, 18 STAN. L. REv. 929 (1966). The Court resolved this issue in Norfolk Southern Railway v. Sorrell, 549 U.S. 158 (2007), holding that the same standard applied to both plaintiff and defendant negligence.

7. Act of Apr. 22,1908 , ch. 149,35 Stat. 65 (codified as amended at 45 U.S.C. $\S 51$ ). As with other worker reform statutes of the era, the Supreme Court held the first version of the Act, passed by Congress in 1906, unconstitutional. The Employers' Liability Cases, 207 U.S. 463, 499 (1908). Congress attended to the problems identified in the first Act that same year and passed a revised version that the Court later upheld.

8. See, e.g., Kenneth S. Abraham, The Liability Century 42-43 (2008); Orin Kramer \& Richard Briffault, Workers Compensation: Strengthening the Social Compact 1-3 (1991); see also Price V. Fishback \& Shawn Everett Kantor, The Adoption of Workers' Compensation in the United States, 1900-1930, 41 J.L. \& Econ. 305, 319-20 (1998) (claiming that changes in tort law favorable to plaintiffs encouraged employer support for workers' compensation legislation).

9. See Richard A. Posner, The Federal Courts: Crisis and Reform 184 (1985) (explaining the lack of reasons for contemporary maintenance of the FELA). By contrast, occupational injuries to longshoremen and other harbor workers are necessarily a federal matter to those workers because of the federal government's exclusive authority over admiralty. See S. Pac. Co. v. Jensen, 244 U.S. 205, 214-15 (1917).

10. Although my focus is the FELA, the problems I identify are equally applicable to seamen's suits against their employer under the Jones Act. 46 U.S.C. app. \$ 688(a) (2006). Congress adopted the FELA by reference to govern those suits. See Kernan v. Am. Dredging Co., 355 U.S. 426, 439 (1958) (applying FELA principles to claims made under the Jones Act).

11. The toll on railroad workers, as one might have expected, was particularly heavy. One frequently cited statistic from the late nineteenth century is that a railroad brakeman had an almost eighty percent chance of dying prematurely. See INTERSTATE Commerce Comm'N, 
ees, with the trilogy of defenses that employers frequently asserted with success. ${ }^{12}$ That situation is part of the well-known history that led to workers' compensation. ${ }^{13}$ Yet, there was another, less frequently told aspect to the tort law of the late nineteenth and early twentieth centuries that contributed to the dismal fate of injured employees. Courts ruled in cases on factual matters with little deference to the role of the jury, often without even a nod in the direction of "sufficiency of the evidence" or whether a reasonable jury could have found otherwise. ${ }^{14}$

Workers' compensation systems had been established in Europe, initially in Germany. ${ }^{15}$ The toll of the industrial revolution was no less in the United States, and President Theodore Roosevelt made the issue of workplace safety a priority. ${ }^{16}$

Third Annual Report 85 (1889); see also Mark Aldrich, Death Rode the Rails: AmeriCAN RaIlROAD ACCIDENTS AND SAFETy 1828-1965, at 103-07 (2006); WALter Licht, Work. ing for the Railroad: The Organization of Work in the Nineteenth Century 190-97 (1983); John Fabian Witt, The Accidental Republic: Crippled Working Men, DestitUTE Widows, AND the Remaking of AMERICAN LAw 3 (2004); Griffith, supra note 5, at 162; Havens \& Anderson, supra note 5, at 310.

12. These defenses included contributory negligence and assumption of risk, which were applicable to all tort cases of the era, and the fellow-servant rule, which was peculiar to the workplace and exempted an employer from vicarious liability when the plaintiff was an employee. See Kramer \& Briffault, supra note 8, at 14-15; Lawrence M. Friedman \& Jack Ladinsky, Social Change and the Law of Industrial Accidents, 67 Colum. L. REv. 50, 51-53 (1967) (discussing the fellow-servant rule).

13. As Bob Rabin put it, "Deep-seated dissatisfaction with accident law dates back at least to the rise of the railroad as an engine of destruction ...." Robert L. Rabin, Some Reflections on the Process of Tort Reform, 25 S AN Diego L. Rev. 13, 15 (1988). A less-well-known aspect of the story is that the harshness of the law toward occupational injuries was in the process of being liberalized in the run-up to workers' compensation. See, e.g., LicHT, supra note 11, at 197-99; Friedman \& Ladinsky, supra note 12, at 59-65.

14. The Missouri Supreme Court provides an example in Rogers, a case in which the U.S. Supreme Court set forth the standard for causation discussed in this Article. Rogers v. Thompson, 284 S.W.2d 467 (Mo. 1955), rev'd sub nom. Rogers v. Mo. Pac. R.R., 352 U.S. 500 (1957). There, a railroad worker allegedly fell due to dangerous work conditions at the site where he had been assigned to burn off weeds on the railroad roadbed. Addressing proximate cause, the Missouri court stated, "And now, after the event, we are obliged to say we think plaintiff's injury was not the natural and probable consequence of any negligence of defendant." Id. at 472 . The court made this conclusion in the course of reversing a jury verdict and judgment entered on behalf of the plaintiff, id. at 473 , despite many years of (and a large number of reversals by) the Supreme Court attempting to wean lower federal courts and state courts from the practice of ruling as a matter of law on sufficiency of the evidence grounds. See infra notes 99-102 and accompanying text.

15. See Lee K. Frankel \& Miles M. Dawson, Workingmen's Insurance in Europe 3 (1910); John M. Kleeberg, Note, From Strict Liability to Workers' Compensation: The Prussian Railroad Law, the German Liability Act, and the Introduction of Bismarck's Accident Insurance in Germany, 1838-1884, 36 N.Y.U. J. INT'L L. \& Pol. 53 (2003).

16. See WIrT, supra note 11, at 2-4. President Roosevelt was not the first U.S. President to do so. President Benjamin Harrison had urged Congress repeatedly to enact legislation to address safety for railroad employees. Johnson v. S. Pac. Co., 196 U.S. 1, 19-20 (1904). In 1893, Con- 
In the United States, there was significant concern ${ }^{17}$ about enacting compensation systems to replace tort law because of constitutional provisions protecting the right to jury trial, the right to a judicial remedy, and separation of powers. ${ }^{18}$ To avoid those obstacles, the first iteration of the FELA, enacted in 1906, retained a system of fault but modified several aspects of common law torts that foiled most injured workers' claims. ${ }^{19}$ The Supreme Court promptly struck down the statute, albeit on different grounds from the ones feared. ${ }^{20}$ Instead, the Court held that Congress lacked the authority to enact the legislation because the railroad workers covered went beyond that permitted by the Interstate Commerce Clause. ${ }^{21}$ That problem was rapidly addressed, and the second version of the FELA was enacted in 1908.22 Thus, although enacted around the framework of tort law, the FELA was the product of the same societal concerns that produced workers' compensation and was intended to accomplish similar goals. In one sense, the FELA was the first workers' compensation statute in this country. ${ }^{23}$

The FELA addressed the unholy trinity of employer defenses by replacing contributory negligence with comparative fault, abolishing the fellow-servant rule, and limiting the doctrine of assumption of

gress enacted the first federal safety regulation. Act of Mar. 2, 1893, ch. 196, 27 Stat. 531 (codified as amended at 45 U.S.C. $\$ 2$ (1988), recodified as amended at 49 U.S.C. $\S 20302$ (2006)); see also LICHT, supra note 11, at 189-90 (describing its enactment).

17. See, e.g., Liability of Employers: Hearing on H.R. 239, S. I56, \& S. 1657 Before the S. Comm. on Interstate Commerce, 59th Cong. 33-41 (1906) (statement of H. T. Newcomb, representing the Del. and Hudson Canal Co.) (raising concerns under the Commerce Clause); id. at 164-66 (additional statement of H. R. Fuller, representing the Brotherhood of Locomotive Engineers, Brotherhood of Locomotive Firemen, Order of Railway Conductors, and the Brotherhood of Railroad Trainmen) (raising concerns under the Commerce Clause); WrT, supra note 11, at 137 (describing early cases striking down workplace reform legislation); Frank Warren Hackett, The Federal Employers' Liability Act of 1908-Is It Constitutional?, 22 HARv. L. REv. 38 (1908-1909) (discussing whether Congress had the power under the Commerce Clause to enact the FELA); Harry Weiss, Employers' Liability and Workmen's Compensation, in HisTORY OF LABOR IN THE United States, 1896-1932, at 564 (John R. Commons ed., 1966).

18. Indeed, the first effort by Maryland in 1902 to provide an optional workers' compensation system that employers could opt into was struck down on constitutional grounds. George E. Barnett, The End of the Maryland Workmen's Compensation Act, 19 Q.J. ECON. 320, 320-21 (1905). Montana followed in 1909 with legislation that was also struck down on constitutional grounds. Id.

19. Act of June 11, 1906, ch. 3073, 34 Stat. 232 (1906) (abrogating the fellow-servant rule and providing that slight contributory negligence would reduce, but not bar, the plaintiff's recovery).

20. The Employers' Liability Cases, 207 U.S. 463, 492 (1908).

21. Id. at $492-503$.

22. Act of Apr. 22, 1908, ch. 149, 35 Stat. 65 (codified as amended at 45 U.S.C. $\S 51$ ).

23. Although Maryland was the first to establish a non-universal workers' compensation scheme, New York enacted the first comprehensive statute. See Fishback \& Kantor, supra note 8 , at 320 . 
risk. ${ }^{24}$ Shortly thereafter, the Supreme Court held that, like workers' compensation, the FELA is the exclusive remedy for railroad workers to recover from their employer for occupational injury. ${ }^{25}$

In those respects, the FELA marches to the same drummer as the workers' compensation statutes that followed shortly thereafter.

\section{Some Sense About Causation}

One should not wander in the thicket of FELA causation without some framework and terminology as a guide. Making sense of the morass of inconsistencies, misunderstandings, and confusion that suffuse FELA causation decisions requires a compass for the trip. To be sure, much of causation law in the nineteenth and twentieth centuries relied on shibboleths and inapt language that then found their way into jury instructions. The causal language in the FELA, its progressive purpose, and the effort in Rogers to effectuate that purpose, however, set FELA causation on a higher confusion shelf.

Before attempting to provide a modicum of clarity about causation, I begin with the proximate cause landscape when Congress enacted the FELA. At that time, standards for causation were quite different from those discussed in the remainder of this Part.

There were a couple of strands to proximate cause thinking in the late nineteenth and the early twentieth centuries. ${ }^{26}$ One, a product of legal scientism, posited that a proximate cause could logically and objectively be deduced by employing appropriate investigatory tools. ${ }^{27}$ Those tools came from largely meaningless and nonnormative phrases that sound vaguely objective, such as natural and continuous; natural and probable; intermediate efficient causes; active, efficient, and prevailing causes; and intervening events cutting the causal chain. ${ }^{28}$ Note

24. The initial abrogation of assumption of risk was limited to instances in which the railroad violated a safety statute. Act of Apr. 22, 1908, ch. 149, § 3, 35 Stat. 65, 66. In 1939, assumption of risk was completely eliminated. Act of Aug. 11, 1939, ch. 685, 53 Stat. 1404 (codified as amended at 45 U.S.C. $\$ 51$ ).

25. See N.Y. Cent. R.R. v. Winfield, 244 U.S. 147, 151-52 (1917).

26. See Patrick J. Kelley, Proximate Cause in Negligence Law: History, Theory, and the Present Darkness, 69 WASH. U. L.Q. 49, 51-54 (1991) (describing a debate among commentators).

27. See Herbert Hovenkamp, Pragmatic Realism and Proximate Cause in America, 3 J. LEGAL. Hist. 3, 10-22 (1982); James T. Kloppenberg, The Theory and Practice of American Legal History, 106 Harv. L. Rev. 1332, 1340 (1993) (reviewing Morton J. Horwitz, The Transformation of American Law, 1870-1960: The Crisis of Legal Orthodoxy (1992)); James E. Viator, When Cause-in-Fact Is More than a Fact: The Malone-Green Debate on the Role of Policy in Determining Factual Causation in Tort Law, 44 LA. L. Rev. 1519, 1523-24 (1984).

28. See, e.g., Milwaukee \& St. Paul Ry. v. Kellogg, 94 U.S. 469, 475 (1876) ("[W]hen there is no intermediate efficient cause, the original wrong must be considered as reaching to the effect, and proximate to it. The inquiry must, therefore, always be whether there was any intermediate cause disconnected from the primary fault, and self-operating, which produced the injury."); 
that central to this investigation was a unitary concept that addressed both of two distinct elements that tort law recognizes today. At one time, the proximate cause inquiry often, but not always, produced what was known as the "last wrongdoer" rule. ${ }^{29}$ Even Holmes, who announced and applied the last wrongdoer rule in Clifford v. Atlanta Cotton Mills, a case in which there was no real basis for holding the non-last wrongdoer liable, acknowledged that "a man sometimes may

Denny v. N.Y. Cent. R.R., 79 Mass. (13 Gray) 481, 487 (1859) (concluding that defendant's negligence "had ceased to operate as an active, efficient and prevailing cause"); Christianson v. Chi., St. P., M. \& O. Ry., 69 N.W. 640, 641 (Minn. 1896) ("Consequences which follow in unbroken sequence, without an intervening efficient cause, from the original negligent act, are natural and proximate ... ."); Pendroy v. Great N. Ry., 117 N.W. 531, 536 (N.D. 1908) ("[P]roximate cause, within the meaning of the definition of the instruction of the court, is such a cause as operates to produce particular consequences without the interference of any independent, unforeseen cause, without which the injury would not have occurred; or, in other words, proximate cause is the true, probable and natural cause." (internal quotation marks omitted)).

Leon Green published a text on proximate cause shortly after this period that clearly distinguished between factual cause and liability limits, dismissing the language employed by courts to address and categorize causes as so much drivel. Leon Green, Rationale of Proximate CAuse 132-36 (1927).

That nineteenth-century thinking and language still survives-not just in FELA cases-and is revealed in the jury instruction employed by the U.S. District Court for the Eastern District of Texas in an FELA case in the mid-twentieth century:

As used in this charge the term "proximate cause" means that cause which in a natural and continuous sequence produced the event or happening in question and without which such event or happening would not have occurred; and the act or omission in question only becomes a proximate cause of an event or happening when such event or happening is the natural and probably (sic) consequence of such act or omission and is such a consequence as ought to have been foreseen by a person in the exercise of ordinary care in the light of attending circumstances. It need not be the sole cause, but it must be a concurring cause which contributed to the production of the result in question and but for which such result or accident would not have occurred.

Page v. St. Louis Sw. Ry., 312 F.2d 84, 87 (5th Cir. 1963) (alteration in original). The Fifth Circuit held this instruction erroneous because it failed to employ the statutory language requiring that the defendant's negligence play only a part in causing the plaintiff's harm. Id. at 92; see also Oglesby v. S. Pac. Transp. Co., 6 F.3d 603, 608 (9th Cir. 1993) ("[Prior precedent] establishes that it is not prejudicial error for a court to instruct the jury that the alleged [Boiler Inspection Act] violation must be a 'proximate cause' of the injury, or that cause which produces the injury in a 'direct, unbroken sequence' as long as the jury is also instructed that causation is established if the violation played 'any part, no matter how small, in bringing about or actually causing the injury." ").

29. See Clifford v. Atl. Cotton Mills, 15 N.E. 84, 87 (Mass. 1888) ("[T]he general tendency has been to look no further back than the last wrong-doer, especially when he has complete and intelligent control of the consequences of the earlier wrongful act."); see also H. L. A. HART \& Tony Honore, Causation in the Law 277 (2d ed. 1985) (describing the last wrongdoer rule as a reflection of the view that tort law should provide only one person for a plaintiff to sue); Francis Wharton, A Treatise on the Law of Negligence 76-80 (2d ed. 1878) (describing the justification for the rule); Laurence $\mathrm{H}$. Eldredge, Culpable Intervention as Superseding Cause, 86 U. PA. L. REv. 121, 124-25 (1937) (describing the evolution of the last human wrongdoer rule as an aspect of causation and its dissipation in the latter half of the nineteenth century); Hovenkamp, supra note 27, at 4 (explaining the role that the last wrongdoer rule played). 
be liable in tort notwithstanding the fact that the danger was attributable in part to the concurrent or subsequently intervening misconduct of a third person." 30 Yet there was a reasonably well-developed understanding that any outcome was the result of many antecedent necessary conditions. ${ }^{31}$ And in the pre-Realist period, Nicholas St. John Green published an article, though largely ignored at the time, in which he dismissed scientism and objectivity for determining proximate cause. Instead, he claimed that proximate cause had to be determined in light of the purpose for which the inquiry was conducted. ${ }^{32}$ Only after the reason for the inquiry is identified can causes be separated into those that are proximate and those that are remote. ${ }^{33} \mathrm{By}$ the time of the FELA, as Patrick Kelley reports:

Joseph W. Bingham, an early legal realist, brilliantly cut through the varied and confusing explanations given by the courts to the underlying core of the proximate cause doctrine. He concluded, from an intensive analysis of a series of specific cases, that "in those cases decided against defendant, the prevention throughout of the concrete sequence which produced the damage was within the limits of the purposes for which the unperformed duty was imposed; in those decided in favor of defendant, it was not within those limits." 34

The first Restatement of Torts, adopted in 1934, attempted some modest improvements but complicated causation as a result of its reform efforts. ${ }^{35}$ One could insist that the common law treatment of causation in 1908 is the only one that can inform what Congress intended in the FELA. ${ }^{36}$ But because Congress did not adopt the causal language of the day and because the Court has demonstrated some willingness to consider later tort standards to inform its interpretation

30. Clifford, 15 N.E. at $86-87$.

31. See Thomas G. Shearman \& Amasa A. Redfield, A Treatise on the Law of NegliGENCE 7 (1869) ("Probably no injury ever happens for which less than a thousand persons have a certain share of moral responsibility.").

32. Nicholas St. John Green, Proximate and Remote Cause, 4 Am. L. Rev. 201, 211-14 (1870).

33. Id. at 213-14.

34. Patrick J. Kelley, Restating Duty, Breach, and Proximate Cause in Negligence Law: Descriptive Theory and the Rule of Law, 54 VAND. L. REv. 1039, 1061 (2001) (footnote omitted) (quoting Joseph W. Bingham, Some Suggestions Concerning "Legal Cause" at Common Law, 9 Colum. L. Rev. 16, 35 (1909)).

35. See Leon Green, The Torts Restatement, 29 Nw. U. L. Rev. 582, 603, 606-07 (1935).

36. See Norfolk \& W. Ry. v. Ayers, 538 U.S. 135, 164 (2003) (Ginsburg, J.) (stating that the state of the law on joint and several liability when the FELA was enacted is "more important" than "the modern trend ... to apportion damages between multiple tortfeasors").

Justice Ginsburg's causal interpretive standard in Ayers is odd. One might think that, as with other statutory construction, the Court is bound by the statute and Congress's intent when it was enacted. Thus, the Court would ask whether Congress incorporated tort law as it existed in 1908 and, if it did, what that tort law was. Perhaps Congress intended to have the FELA interpreted to remain consistent with the evolving law of torts, but that does not detract from the keystone being what Congress intended when it enacted the FELA. 
of the FELA, ${ }^{37}$ both for the sake of providing a framework and to bring some coherence to the FELA, I proceed with an effort to set forth a straightforward and coherent account of the basics of causation that might clarify the FELA and its causal requirement. Selfconsciously, but unapologetically, I draw on the Restatement (Third) of Torts. ${ }^{38}$

There are two elements of a tort case affiliated with the term proximate cause: (1) the factual causal relationship between the defendant's tortious conduct and the plaintiff's harm and (2) limitations on the extent of a defendant's liability to those who suffer harm that the defendant tortiously causes. ${ }^{39}$ Simply stating these two roles reveals that they are quite different functions that we should keep separate from each other in both legal discourse and jury instructions for at least two reasons: (1) when only one of these elements is genuinely in dispute, there is no reason to instruct or submit the other element to the jury and (2) leaving them entangled creates confusion in legal discourse about which element is at issue. ${ }^{40}$

With regard to factual cause, there really is no viable alternative to sine qua non, or its less ostentatious synonym, "but for." If a defendant's conduct is not a necessary condition for the plaintiff's harm, it quite simply lacks the essential connection that is the glue for all tort claims. Yes, there are problems with difficulties of proof for which we sometimes make accommodations. And yes, there is a supplement for but for when there are multiple independent sufficient causes of a plaintiff's harm. ${ }^{41}$ And finally yes, the "substantial factor" test for causation has had considerable sway throughout the United States largely through its adoption in both of the first two Restatements. ${ }^{42}$ Nevertheless, embedded in the substantial factor test, at least in the Restatements, is a but-for requirement. ${ }^{43}$

37. See id. at 184 (Breyer, J., concurring in part and dissenting in part) (suggesting that the Court should interpret the FELA in the same manner as would a court deciding an uncertain issue in a common law case).

38. Restatement (Third) of Torts: Liab. for Physical \& Emotional Harm (2010). The author served as co-reporter for this Restatement.

39. See id. \& $29 \mathrm{cmt}$. g.

40. See id.

41. See id. $\$ 27$.

42. The reason for leaving the substantial factor test behind in the Restatement (Third) of Torts, despite considerable popularity, is explained in a comment. Id. $\S 26 \mathrm{cmt}$. j.

43. See Restatement (Second) of Torts § 432(1) (1965). The first Restatement of Torts contains a virtually identical section. RESTATEMENT OF TORTS $\S 432(1)$ (1934). 
There are three important corollaries to but for as the basis for factual cause. First, causation is not a matter of degree. ${ }^{44}$ Conduct is a cause of harm or it is not; there is no middle ground. ${ }^{45}$ Causes cannot be weak, nor can they be strong; they are or they are not. Second, tortious conduct need only be $a$ factual cause of harm, not the cause of harm. There are always multiple causes of an outcome, although tort law is usually uninterested in most of them. Third, the idea of multiple causes of an accident must be distinguished from multiple competing, but mutually exclusive, causes for an accident. ${ }^{46}$ Unfortunately, the history of FELA adjudications is replete with instances of courts confusing these two causal scenarios, so I tarry to explain. Perhaps the best way to explain the difference between multiple causes and multiple competing causes is to utilize two illustrations.

44. There is, however, the exception of outcomes that are a matter of degree, such as happiness. But the traumatic injuries that are the staple of the FELA are not a matter of degree. With the emergence of diseases from toxic exposure in the FELA mix, those diseases that are progressive, such as asbestosis, may link to exposures that contribute as a matter of degree to the severity of a claimant's condition.

45. See Sandford v. Chevrolet Div. of Gen. Motors, 642 P.2d 624, 630 (Or. 1982) ("In less obvious situations where the physical course of events is in doubt, if either party convinces the factfinder that its misconduct in fact was not a cause of the injury, there is no occasion for allocating partial damages."); Restatement (ThIRD) OF TORTS: APPORTIONMENT OF LiaB. $\S 8$ cmt. a (2000) ("Assigning shares of 'causation' wrongly suggests that indivisible injuries jointly caused by two or more actors can be divided on the basis of causation."). Notwithstanding the unassailability (and my dogmatic insistence) of this principle, there is much to the contrary in the legal literature. See, e.g., Murray v. Fairbanks Morse, 610 F.2d 149, 159 (3d Cir. 1979); Thibault v. Sears, Roebuck \& Co., 395 A.2d 843, 850 (N.H. 1978); Duncan v. Cessna Aircraft Co., 665 S.W.2d 414, 429 (Tex. 1984); Warren A. Seavey, Principles of Torts, 56 HARv. L. Rev. 72, 89 (1942) ("A negligent person is not liable to another unless his negligence is, in some degree, a factual cause of harm."). To paraphrase Walter Wheeler Cook, the tendency to believe that causation is a matter of degree has all the tenacity of original sin and must be constantly guarded against. See Walter Wheeler Cook, "Substance" and "Procedure" in the Conflict of Laws, 42 YALE L.J. 333, 337 (1933).

46. See Restatement (Third) of Torts: Liab. for Physical \& Emotional Harm $\$ 26$ cmt. i (2010). 


\section{Figure 1: Multiple Causes}

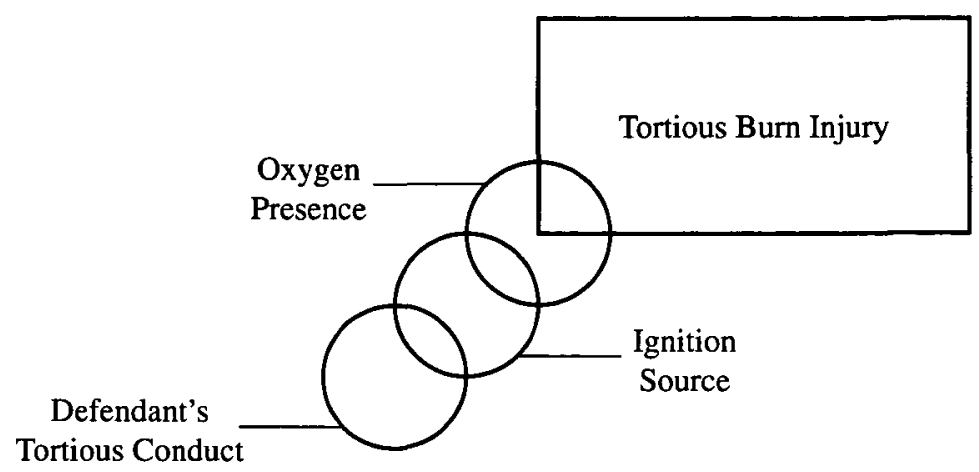

Figure 1 reveals three of the necessary conditions for the burn suffered by a tort plaintiff: (1) the defendant's negligent storing of flammable material (2) in a place where there is the potential for an ignition source and (3) the presence of oxygen to enable a fire to burn. Each one is a but-for cause of the hypothetical burn injury, although only the tortiously created one would be relevant in a tort suit.

\section{Figure 2: Multiple Competing Causes}

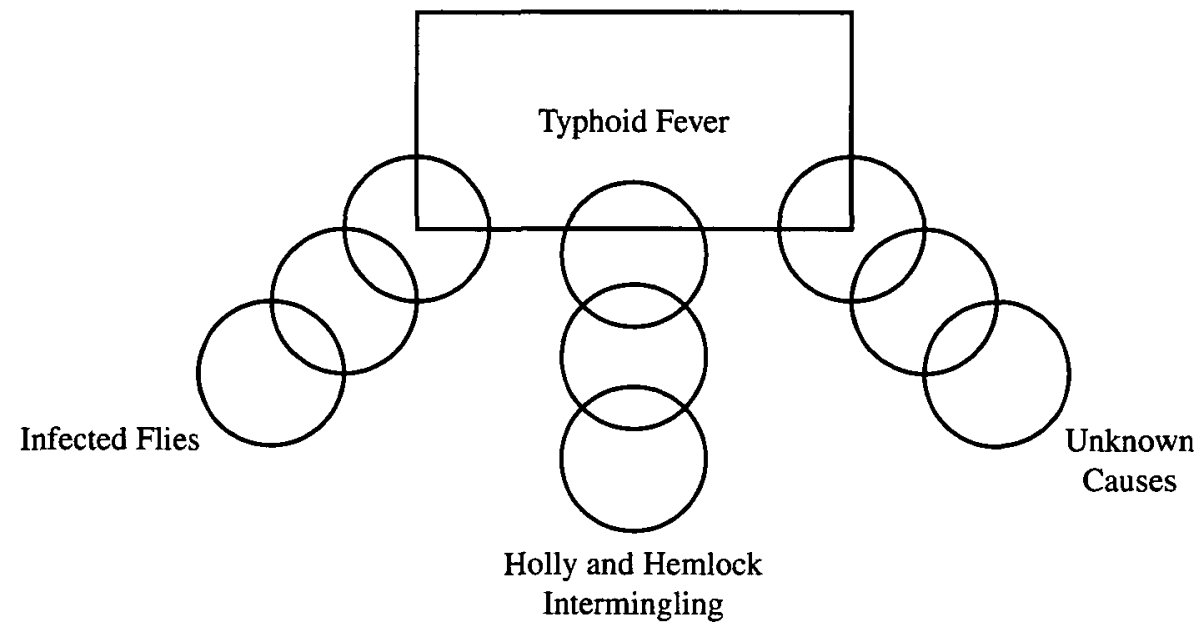

Figure 2 is based on Stubbs v. City of Rochester, in which the plaintiff contracted typhoid fever, allegedly as the result of the defendant's negligence in intermingling drinking water with water for fire fighting that had been contaminated with sewage. ${ }^{47}$ However, other potential causes of typhoid fever existed, and the issue was whether the contam- 
inated water or one of the other sources had been the cause of the plaintiff's disease. ${ }^{48}$

There is one important qualification on the first corollary that causation is not a matter of degree. It is not, but risk contribution can be. So we might, in considering a victim of lung cancer, assess the ex ante risks posed by her smoking and the risk of occupational exposure to asbestos. We can compare those risks as a matter of degree and even quantify them; asbestos exposure increases the risk of lung cancer by about six times and smoking by about twelve times. ${ }^{49}$ Similarly, we might compare the risks posed by exposure to different doses of a toxic agent provided by different defendants. Risk contribution is a matter of degree, and, in the face of intractable problems of proving causation, some courts have employed risk contribution instead of causation, ${ }^{50}$ and other courts have used risk contribution as a basis for apportioning among defendants. ${ }^{51}$ But this is not factual causation that is being compared. And while quantitative evidence of risk contribution is sometimes available in toxic substance litigation based on epidemiology, it is almost never available for the traumatic injuries that are the staple of FELA litigation.

With regard to limiting a defendant's liability for harm that is nonetheless caused by her tortious conduct, proximate cause is a poor term to employ. ${ }^{52}$ The history of its usage to mean either factual cause, scope of defendant's liability, or both provides an environment in which clarity is impossible and confusion festers. ${ }^{53}$ The idea of prox-

48. Id. at 138. This assumes that only one of the competing causes was involved in the plaintiff's typhoid fever. If there were more than one, each independently sufficient, the causal standard would be different. See Restatement (Third) of Torts: Liab. for Physical \& EMOTIONAL HARM $\$ 27$ (2010).

49. See Report of the Surgeon General, The Health Consequences of Smoking: Cancer and Chronic Lung Disease in the Work Place (1985) (explaining the relative risk of dying due to lung cancer for those exposed occupationally to asbestos is 5.2; relative risk for smokers is 10.9; and relative risk for smokers who are also exposed to asbestos is 53.2).

50. See Rutherford v. Owens-Ill., Inc., 941 P.2d 1203, 1223 (Cal. 1997); Sienkiewicz v. Greif (UK) Ltd., [2011] UKSC 10.

51. E.g., Dafler v. Raymark Indus., Inc., 611 A.2d 136, 147 (N.J. Super. Ct. App. Div. 1992).

52. The Restatement (Third) of Torts states: "There may be no legal term in as widespread usage as proximate cause that has been as excoriated as it has. One searches in vain to find a defender of the term; its critics are legion ...." RESTATEMENT (THIRD) OF TORTS: Liab. FOR Physical \& Emotional Harm $\$ 29$ reporters' note to cmt. b (2010). Dean Prosser declared, "Proximate cause remains a tangle and a jungle, a palace of mirrors and a maze ..." William $\mathrm{L}$. Prosser, Proximate Cause in California, 38 CALIF. L. Rev. 369, 369 (1950). Proximate cause "is a complex term of highly uncertain meaning" that "covers a multitude of sins." Id. at 374; see also Leon Green, Jury Trial and Proximate Cause, 35 Tex. L. Rev. 357, 358 (1957) ("The "proximate cause' doctrine, with all of its variations in meaning, is the most imprecise and most confusing of all tort-law doctrines.").

53. See Joseph A. Page, Torts: Proximate Cause 3 (2003). 
imity, either in time or space, has very little to do with determining the point at which a defendant should no longer be held liable for the consequences of her tort-consider asbestos defendants who may have operated thousands of miles and decades away from their victims. Consequently, I use "scope of liability" in this Article to refer to a limitation on liability, ${ }^{54}$ reverting to proximate cause only when essential in describing what a court said or did, or when the context requires, as with the following discussion of "sole proximate cause."

There are three predominant standards employed over the past 150 years to limit a defendant's liability. ${ }^{55}$ First, a direct-remote test in which a judgment is required to determine whether the plaintiff's harm was directly caused by the defendant's tort or, on the other hand, was too remote for liability to attach. That test fits more comfortably with proximate cause, which resembles directness, in contrast with remoteness, with its implication of nearness (of something). While the direct-remote test had considerable sway ${ }^{56}$ in the nineteenth and early twentieth centuries and was fertilized ${ }^{57}$ in the United States by the decision of the English Court of Appeals in Polemis, ${ }^{58}$ it no longer plays a dominant role. ${ }^{59}$ The second test is one relying on foreseeability - whether in some general sense the harm that befell the plaintiff was the foreseeable result of defendant's negligence. ${ }^{60} \mathrm{Fi}$ nally, there is harm within the risk, the standard identified by Joseph Bingham in 1909 as one that emerged from reading the case law. ${ }^{61}$ In

54. No-duty rulings are another way in which defendants' liability may be limited. See Restatement (Third) of Torts: Liab. For Physical \& Emotional Harm $\$ 7$ (b) (2010). However, it has no role in the FELA context because Congress did not authorize it and courts have not adopted no-duty rules for occupational railroad injuries.

55. See PAGE, supra note 53, at 39-71.

56. See id. at $39-43$.

57. See id.

58. See In re An Arbitration Between Polemis and Another and Furness, Withy \& Co., [1921] 3 K.B. 560 at 577.

59. See PAGE, supra note 53, at 31.

60. It is hard to know whether the ascendency of foreseeability in the latter part of the twentieth century in the United States was influenced by its adoption by English courts in a decision that is popularly known as Wagon Mound. See Overseas Tankship (U.K.) Ltd. v. Morts Dock \& Eng'g Co. (Wagon Mound), [1961] A.C. 388. Judge Friendly reported in 1964, with dubious support, "The weight of authority in this country rejects the limitation of damages to consequences foreseeable at the time of the negligent conduct when the consequences are ' $\mathrm{di}$ rect'...." In re Kinsman Transit Co., 338 F.2d 708, 724 (2d Cir. 1964).

61. Joseph W. Bingham, Some Suggestions Concerning "Legal Cause" at Common Law (pts. 1 \& 2), 9 Colum. L. Rev. 16 (1909), 9 Colum. L. Rev. 136 (1909); see also Seavey, supra note 45, at 90-92. The Restatement (Third) adopts the following standard for scope of liability: "An actor's liability is limited to those harms that result from the risks that made the actor's conduct tortious." Restatement (Third) of Torts: Liab. for Physical \& Emotional Harm § 29 (2010). 
1942, Warren Seavey described this as the test for scope of liability, rejecting a role for proximity of time or remoteness in the sense of intervening events. ${ }^{62}$ The extent of flux in the test employed by courts, if not the intermingling of multiple tests in the same case, is revealed by the fact that in the thirty years between the first and fifth editions of the then-leading Shearman and Redfield treatise on negligence, it switched from a direct-remote to a foreseeability test as the appropriate standard for proximate cause. ${ }^{63}$

Regardless of which one of these formulations is adopted, or even if one of the less coherent formulations is employed, some limit on liability must exist. Otherwise, as I observe to my students, Eve, having been negligent per se in violating God's law, would be liable for all the illness, disease, and misery that have befallen the human race since we were expelled from the Garden of Eden.

Notwithstanding that example of truly unlimited liability, in many tort cases there is no serious scope of liability issue. If a soda bottle explodes in a patron's hand because the glass is defective, we would expect the parties to agree that if there is breach and factual cause, no scope of liability issue requires litigation. ${ }^{64}$ And if the defendant will not so stipulate, judgment as a matter of law should be available routinely. The situation is similar with ordinary automobile accidents.

The language of proximate cause used for jury instructions at the time when the FELA was enacted deserves some further consideration. That language, attributable to an approach to law whose day is long past, cannot stand the test of critical scrutiny. What, for example, is an unnatural, as distinguished from a natural, cause? Indeed, what does nature have to do with causation? Are there causal sequences that are discontinuous? I have never seen one identified, although no doubt they are conjured in jury deliberations brought on by instructions that employ this language. The idea that a cause must be probable to be within the scope of liability may have a superficial appeal, given its connection to the standard of proof. But this issue is not about whether the standard of proof is met, but rather with the sub-

62. Seavey, supra note 45 , at $91-92$ ("The fact that there is a long space of time or series of events intervening between the negligent act and the harm does not prevent liability.").

63. Compare Shearman \& Redfield, supra note 31 , at 7 , with Thomas G. Shearman \& amasa A. Redfield, A Treatise on the Law of Negligence 29-32 (5th ed. 1898). Another treatise of this era unselfconsciously contains both a foreseeability and direct-remote standard for proximate cause while making no effort to reconcile them. See I Francis Hilliard, The Law of Torts or Private Wrongs 89 (4th ed. 1874).

64. See Restatement (Third) of Torts: Liab. for Physical \& Emotional Harm $\$ 29$ cmt. a (2010) ("Ordinarily, the plaintiff's harm is self-evidently within the defendant's scope of liability and requires no further attention."); PAGE, supra note 53, at 12-13. 
stantive standard itself. Whether tortious conduct is a probable cause of harm depends not on any inherent characteristic of the conduct, but on whether the other necessary conditions to produce the harm are present. ${ }^{65}$ Very little tortious conduct is, when it occurs, more likely than not to cause harm-even powerful carcinogens and teratogens may have a less-than-even likelihood of causing cancer or birth defects. ${ }^{66}$ To be sure, tortious conduct must likely have been a factual cause of plaintiff's harm, but that is for purposes of the burden of proof for factual cause, not scope of liability. Finally, can anyone provide criteria for sorting efficient causes from inefficient ones? All of this language is, as court opinions and serious critics have recognized, so much claptrap, ${ }^{67}$ yet with a veneer of plausibility that explains its persistence. ${ }^{68}$

Whether a defendant's tortious conduct is within the scope of liability is a binary determination. Either the defendant is or is not liable, just as a defendant's conduct is determined to be or not to be a proximate cause of harm. However, unlike factual cause, scope of liability

65. See Kenneth J. Rothman et al., Modern Epidemiology 7 (3d ed. 2008) ("[A] characteristic of the naive concept of causation is the assumption of a one-to-one correspondence between the observed cause and the effect.... Thus, the flick of a switch appears to be the singular cause that makes an electric light go on. There are less evident causes, however, that also operate to produce the effect: a working bulb in the light fixture, intact wiring from the switch to the bulb, and voltage to produce a current when the circuit is closed.").

66. See Robin Kundis Craig et al., Toxic and Environmental Torts 705 (2011) ("The lifetime risk of contracting lung cancer for smokers is less than $20 \%$ and considerably lower for nonsmokers .....").

67. See Mitchell v. Gonzales, 819 P.2d 872, 877 (Cal. 1991) (en banc) (criticizing the syntax of the instruction that suggests that the tortious act itself must proceed in a natural and continuous sequence, thereby failing to acknowledge that other causes may also exist in the chain that ultimately produces the plaintiff's injury); Stoneburner v. Greyhound Corp., 375 P.2d 812, 816 (Or. 1962) (Goodwin, J., specially concurring) ("Whether the injury is a natural or probable result of negligence gets us nowhere."); Robert E. Keeton, Legal Cause in the Law of Torts 26-28 (1963) (criticizing the natural and probable formulation); Eldredge, supra note 29, at 123 ("Nor is clarity attained by the repetitious utterance of a ritualistic formula about 'natural and probable consequences." "); Hovenkamp, supra note 27, at 5, 18 (noting that the terminology was "absolute nonsense" and "a hopeless entanglement of unverifiable terms and metaphysical ideas"); Kelly, supra note 34, at 1042 ("[O]rdinary jury instructions do not clearly separate the cause-infact question from the proximate cause questions and give little guidance on how either question is to be resolved."); Prosser, supra note 52, at 424 ("There are probably few judges who would undertake to say just what this means, and fewer still who would expect it to mean anything whatever to a jury."); Jane Stapleton, Legal Cause: Cause-in-Fact and the Scope of Liability for Consequences, 54 VAND. L. REv. 941,987 (2001) ("[T] he inadequacy and vagueness of jury instructions on 'proximate cause' is notorious."); see also Shadday v. Omni Hotels Mgmt. Corp., 477 F.3d 511, 513 (7th Cir. 2007) (criticizing intervening and superseding cause explanations for no liability as "legal mumbo-jumbo").

68. While this language has yet to be completely extinguished from current court opinions and jury instructions, it is rejected in the Restatement (Third) of Torts. Restatement (THIRD) of Torts: Liab. for Physical \& Emotional HaRM $\S 29$ reporters' note to cmt. b (2010). 
is a matter of degree and requires that a line be drawn at the point at which tortious conduct will subject the actor to liability. ${ }^{69}$ Thus, "directness" or its antonym, "remoteness," is a matter of degree and requires a judgment about just how remote tortious conduct and harm must be for liability not to be imposed. Similarly, harms can be more or less foreseeable, as revealed by the frequently invoked "reasonably foreseeable" test. ${ }^{70}$ Some harms arise more centrally from the risks that made the defendant negligent while other harms are less clearly so. ${ }^{71}$

Thus, a statement that the FELA adopted "a relaxed standard of causation" makes no sense in relation to factual cause because factual cause is not a matter of degree. ${ }^{72}$ It might make sense if applied to scope of liability because it encompasses a range of foreseeability.

As with factual cause, there can be multiple tortfeasors who are liable for the same harm. The reporters are littered with cases that amply demonstrate this rule. ${ }^{73}$ So what might we make of the term sole proximate cause? ${ }^{74}$ It is important to address this issue before discussing Rogers because sole proximate cause has a significant history in

69. Thus, the Uniform Comparative Fault Act $\S 2$ (b), 12 U.L.A. 135 (2008), permits consideration both of the tortious conduct and "the causal relation between the conduct and the damages claimed" in apportioning comparative fault among the parties. The "causal relation" referred to is proximate cause because tortious conduct must be a factual cause of harm and cannot be compared. See supra notes 44-45 and accompanying text.

70. 1 Dan B. Dobbs et al., The Law of Torts $\$ 202$ (2d ed. 2011).

71. For example, consider an automobile accident that results from a brake failure caused by improper and negligent repairs by a mechanic. The harms resulting from the accident would be squarely within the mechanic's scope of liability. Alternatively, suppose the driver had been able to maneuver the brakeless automobile onto the shoulder and stop it without incident. If, while sitting on the roadside, another driver ran into the automobile injuring the occupants, their injuries would be less clearly within the mechanic's scope of liability-indeed, they might be beyond that liability boundary.

72. Consol. Rail Corp. v. Gottshall, 512 U.S. 532, 543 (1994).

73. See, e.g., In re Kinsman Transit Co., 338 F.2d 708, 719 (2d Cir. 1964) ("Save for exceptions which are not here pertinent, an actor whose negligence has set a dangerous force in motion is not saved from liability for harm it has caused to innocent persons solely because another has negligently failed to take action that would have avoided this."); see also RESTATEMENT (THIRD) of Torts: Liab. For Physical \& Emotional Harm $\$ 34 \mathrm{cmt}$. a (2010) ("[T]here are always multiple causes of an outcome and . . . the existence of intervening causes does not ordinarily elide a prior actor's liability.").

74. The term has no precise meaning and has been variously employed to mean no negligence as a matter of law, see S. Ry. v. Youngblood, 286 U.S. 313, 317-18 (1932), or the defendant's negligence is not a factual cause of harm. See Van Buskirk v. Carey Can. Mines, Ltd., 760 F.2d 481, 493-95 (3d Cir. 1985); see also Archambault v. Soneco/Ne., Inc., 946 A.2d 839, 849-53 (Conn. 2008) (permitting proof of sole proximate as a method to disprove the defendant was a cause of the plaintiff's injury). The most common usage is as an alternative to superseding cause when another's tortious conduct intervenes in a sufficiently unforeseeable manner as to render the original tortfeasor's conduct outside the scope of liability. See, e.g., Budden v. United States, 15 F.3d 1444, 1449-50 (8th Cir. 1994). 
tort law and frequently makes an appearance in FELA opinions. ${ }^{75}$ For the sake of brevity and simplicity, I confine this discussion to sole proximate cause as between the plaintiff and the defendant. We need not canvass the complications that ensue when there are others committing tortious acts because of contexts in which sole proximate cause issues arise in FELA cases. The occupational risks to which railroad workers are subject are almost always limited to those created by their employer and their co-workers. Third parties rarely play a role in railroad injuries so that sole proximate cause in reference to multiple parties creating risks can be put aside. Instead, sole proximate cause emerges when both the plaintiff and the defendant play, or may have played, a role in the plaintiff's harm.

For factual cause purposes, most invocations of sole proximate cause are at best confusing due to their indirection. Remember that there are always multiple causes of tortious harm, and there is no basis, other than on noncausal grounds, to identify one as the sole factual cause. The one circumstance in which sole proximate cause is coherent, but entirely unnecessary, is when there are mutually exclusive alternative causes, as reflected in Figure 2 above. One of the multiple competing causal chains is responsible for the plaintiff's harm, but only one. To say that the one including the plaintiff's contributory negligence is the sole proximate cause means that the one with the defendant's negligence is not a factual cause. Thus, a clearer and more direct way to describe this situation is to say that the defendant was not a factual cause of the harm.

For scope of liability purposes, concluding that an actor's conduct is the sole proximate cause of a harm means that others, whose tortious conduct is also a factual cause of the harm, are not liable for the harm. The same judgment is involved when a superseding cause is said to avoid the earlier tortfeasor's liability-often couched in gibberish about "cutting the causal chain," and thereby invoking a term that looks faintly like factual cause. ${ }^{76}$

During the era when contributory negligence constituted a complete defense, tagging a plaintiff's negligent conduct as the sole proximate cause of harm was benign, if imprecise. Plaintiffs whose contributory negligence was not a sole proximate cause still lost their suit because of the complete bar of contributory negligence. How-

75. Rogers v. Mo. Pac. R.R., 352 U.S. 500, 506 (1957).

76. See, e.g., Budden, $15 \mathrm{~F} .3 \mathrm{~d}$ at 1450 ("[T]he district court's proximate cause determination rests on the proposition that [the plaintiff's decedent's] conduct broke the causal connection between [the defendant's employee's] breach of duty and the crash and operated as the sole proximate cause of the accident."). 
ever, the same cannot be said once comparative fault replaced contributory negligence-recall that the FELA, right from the start, abrogated contributory negligence, replacing it with comparative fault. When sole proximate cause or its equivalent, superseding cause, is used to deny a plaintiff recovery, it constitutes a linguistic subterfuge for evading the rule of comparative fault, ${ }^{77}$ which explains why sole proximate cause has become such a popular defense after comparative fault was adopted. ${ }^{78}$

The analysis above proceeds on the assumption that the harm is within the scope of the defendant's liability. However, if it is not, then there is a straightforward reason for denying liability; sole proximate cause is unnecessary and directs our attention away from a simple and clear explanation for the outcome. Given its lack of any clear meaning, the availability of more accurate and conventional explanations for each of its usages, and its potential to undermine the rule of comparative fault, sole proximate cause has no useful contribution-and some detriment-in modern tort usage. ${ }^{79}$

\section{Nonsense About Causation}

I entered into this endeavor with enthusiasm, curious about what I would find about the relationship between tort law and alternative

77. See, e.g., Everly v. Columbia Gas of W. Va., Inc., 301 S.E.2d 165, 166-68 (W. Va. 1982); John G. Phillips, The Sole Proximate Cause "Defense": A Misfit in the World of Contribution and Comparative Negligence, 22 S. IL.. U. L.J. 1, 1-3 (1997); David W. Robertson, Love and Fury: Recent Radical Revisions to the Law of Comparative Fault, 59 LA. L. Rev. 175, 196 (1998); David W. Robertson, The Texas Employer's Liability in Tort for Injuries to an Employee Occurring in the Course of the Employment, 24 St. MARY's L.J. 1195, 1200 (1993).

Exxon Co., U.S.A. v. Sofec, Inc., 517 U.S. 830 (1996), is the leading case that justifies the use of a plaintiff's conduct as a superseding cause notwithstanding comparative responsibility, and it is frequently criticized for that stance. See, e.g., David W. Robertson, Eschewing Ersatz Percentages: A Simplified Vocabulary of Comparative Fault, 45 Sr. Lous U. L.J. 831, 841-42 (2001); Kelsey L. Joyce Hooke, Comment, Collision at Sea: The Irreconcilability of the Superseding Cause and Pure Comparative Fault Doctrines in Admiralty, 74 WASH. L. REv. 159, 159-60 (1999). For an interpretation of Sofec that avoids a conflict with comparative fault, see Michael D. Green, The Unanticipated Ripples of Comparative Negligence: Superseding Cause in Products Liability and Beyond, 53 S.C. L. Rev. 1103, 1125-27 (2002).

78. Thus, in Rogers, there was discussion of the plaintiff's failure to keep a proper lookout when a train passed by his position. 352 U.S. at 503-04. Perhaps that constituted fault, which would, under the FELA, reduce his recovery. No comparative fault instruction was given, but the jury was instructed about whether plaintiff's negligence was the sole proximate cause of the accident. Id. at 504-05 \& n.9. Such an instruction runs headlong into the elimination of contributory negligence in the FELA and adoption of contributory negligence in its place.

79. The Restatement (Third), after cataloging the different usages of the term and commenting on the availability of other, more precise explanations, concludes: "In light of the confusion it can generate, and of the availability of more precise explanations for denying liability, it is a term best avoided." Restatement (Third) of Torts: Liab. for Physical \& Emotional HARM $\$ 34 \mathrm{cmt}$. f (2010). 
compensation systems reflected in the FELA. Instead, I rapidly began to feel the way Alice did after falling down the rabbit hole. My reaction after reading a significant body of FELA cases was, to borrow from her sentiment, "It would be so nice if something made sense for a change!" 80

Much of the confusion and nonsense about the standard for causation in FELA cases can be laid at the feet of Justice Brennan's opinion in Rogers v. Missouri Pacific Railroad Co., the case in which the Supreme Court characterized the causal test under FELA as requiring only that the "negligence played any part, even the slightest, in producing the injury." 81 The case, in its treatment of causation, is, to be blunt and colloquial, a train wreck. It mischaracterizes what the lower court did, confuses and conflates factual cause and scope of liability, and appears to let its pique and impatience over the continued failure of lower courts to respect the domain of the jury in FELA cases to produce an opinion with a too-casual, truncated analysis and an outcome determinative rush to judgment.

The plaintiff, a laborer employed by the defendant railroad, was working to remove trackside vegetation. ${ }^{82} \mathrm{He}$ was provided a hand torch to burn the already dead vegetation that was on sloping ground on one side of the tracks. ${ }^{83}$ The plaintiff and fellow laborers were instructed to step away from the track when a train passed and to look for "hot boxes," an overheating condition on the train's axle that can lead to fire or derailment. ${ }^{84}$ The plaintiff heard a train approaching, took up a position near a culvert, and began looking at the train for hot boxes. ${ }^{85}$ Suddenly he was engulfed in flames from the vegetation he had been burning when the flames were fanned by the train and, in the commotion and effort to retreat, he fell off of the culvert and was injured in the fall. ${ }^{86}$

Making sense of the relationship between the facts and the charges of negligence in the case is an exercise in frustration, even with the opinions of both the Missouri Supreme Court and the United States Supreme Court. ${ }^{87}$ My best interpretation of the negligence charged

\footnotetext{
80. Alice in Wonderland (Walt Disney Prods. 1951).

81. Rogers, 352 U.S. at 506.

82. Id. at 502 .

83. Id.

84. See Encyclopedia of Railroads 458 (O.S. Nock ed., 1977).

85. Rogers, 352 U.S. at 502.

86. Id.

87. For example, one cannot discern from the Supreme Court's opinion whether the plaintiff's injury was due to burns, falling, or both. Id. One must read the Missouri Supreme Court's opinion to find out that the plaintiff's injury was sustained in the fall. Rogers v. Thompson, 284
} 
by the plaintiff is (1) that requiring him to work in proximity to passing trains at the same time he was starting fires created a dangerous environment that subjected him to a risk of harm and (2) that the culvert from which he fell was in an unsafe condition-sloping, covered with loose gravel, and missing a sufficiently wide footpaththereby creating a risk of harm from falling. ${ }^{88}$ In its treatment of factual and proximate causation, the Missouri Supreme Court did not address the former aspect of negligence. ${ }^{89}$

The Missouri Supreme Court reversed a verdict and judgment for the plaintiff. ${ }^{90}$ In the course of doing so, the court expressed entirely conventional views of factual causation and scope of liability. Factual cause required that the defendant's negligence have a but-for relationship with plaintiff's harm..$^{91}$ In addition to that causal connection, legal or proximate cause (scope of liability) is required,, 92 and the court suggested either a foreseeability criterion or whether, in hindsight, the injury is a natural and probable consequence of the tortious conduct. ${ }^{93}$

After assessing the negligence of the railroad in failing to maintain the condition of the area around the culvert, the court held there was no basis for a finding of negligence. ${ }^{94}$ The foreseeable risks during ordinary use were not sufficient to require taking any precaution. ${ }^{95}$ The court then explained that the emergency confronting the plaintiff was his own doing. ${ }^{96}$ This observation had no operative legal signifi-

S.W.2d 467,468 (Mo. 1955). The harm that occurs is critical to the determination of proximate cause. See supra note 61 and accompanying text.

88. There is also a suggestion that the method of burning off the vegetation chosen by the defendant was negligent, but the Missouri Supreme Court rejected that, and the Supreme Court did not address it. Rogers, 284 S.W.2d at 472.

89. Confusingly, the court distinguished several cases in which dangerous work conditions were sufficient for the jury to find negligence without stating any conclusion about the implications of the distinction. Id. at 470 . The court did, however, appear to dismiss both the vegetation removal methods and the culvert condition as bases for a finding of negligence, leaving the rulings on causation as alternative bases for a decision. Id at 472 . The court only appeared to dismiss these bases because, among other confusing aspects of the opinion, this discussion occurs after the court finishes with comparing removal methods to other cases and introduces the subsequent discussion with, "As to the issue of causal connection ...." Id. at 470 .

90. Id. at 473 .

91. Id. at 471 .

92. Id.

93. See id. The "hindsight" test appeared in $\S 442$ (b) of both the first and second Restatements, albeit as a factor to be considered in determining scope of liability. Compare Restatement of Torts: Negligence § 442(b) (1934), with Restatement (Second) of Torts § 442(b) (1965).

94. Rogers, 284 S.W.2d at 472 ("[T]he culvert was not shown to have been unsafe for workmen in the ordinary use of the area.").

95. Id.

96. Id. 
cance, as the conclusion that the defendant was not negligent resolved the case.

Next, and apparently alternatively, the court concluded that the loose gravel on the sloping ground was not a proximate cause of the plaintiff's harm. ${ }^{97}$ Seemingly unsatisfied with two reasons for reversing the lower court's judgment, the court asserted that factual cause was absent as well because plaintiff had not introduced evidence establishing that any "negligence, in whole or in part, contributed to plaintiff's injury." 98

The U.S. Supreme Court's decision is flawed in numerous respects. A partial explanation for this deficit may be the Court's growing frustration with lower courts that, for decades, consistently took FELA cases away from the jury with only a passing nod in the direction of the insufficiency of the evidence. ${ }^{99}$ Those courts sometimes did so after making credibility judgments that were barely disguised and plainly improper for a court to make. ${ }^{100}$ Indeed, a schism developed in the Court over whether it should continue to correct sufficiency of the evidence errors in FELA cases or relinquish the error-correction

97. Id. ("[P]laintiff's injury was not the natural and probable consequence of any negligence of defendant."). Presumably, the court found that no reasonable jury could have found proximate cause existed for this claim, but, as with many courts of this era, it did not suggest that this is a factual question ordinarily reserved for the jury unless the evidence is such that the court can rule as a matter of law.

One thing that the U.S. Supreme Court might have done in Rogers that would have spared decades of confusion in lower courts would have been to address and resolve whether the FELA requires proximate cause, apart from factual causation, for liability or whether the FELA dispensed with such an element.

98. Id.

99. The Missouri Supreme Court's opinion in Rogers is a reasonably good example. The court wrote, addressing factual cause:

And if there was negligence in failing to maintain a sufficiently wide path across the culvert or in permitting that path to become covered with crushed rock or gravel, still plaintiff's evidence is completely lacking in probative facts supporting a conclusion that defendant's negligence, in whole or in part, contributed to plaintiff's injury.

Id. "Direct evidence" of causation there was not, but causation often requires inference, and an inference from conditions that created a risk of falling could have supported a jury verdict.

100. Thus, in its opinion, the Missouri Supreme Court quoted the plaintiff's testimony contained in the record and observed its inconsistency:

Plaintiff's testimony, which we have quoted in question and answer form, supra, was support for a conclusion that plaintiff slipped on gravel "right up next to the ties"; however, at another time while testifying, plaintiff said, "I didn't back up east, next to the rails."

Rogers, 284 S.W.2d at 472 . For other cases illustrative of courts wielding a heavy hand in ruling on matters that would ordinarily be for the jury, see St. Louis-S.F. Ry. v. Smith, 19 S.W.2d 1102, 1105 (Ark. 1929); Pa. R. v. Johnson, 169 N.E. 358, 362 (Ind. Ct. App. 1929); Wagner v. St. LouisS. F. Ry., 19 S.W.2d 518, 521 (Mo. Ct. App. 1929); Phillips v. Chi., B. \& Q. R., 227 N.W. 931,933 (Neb. 1929); Potter v. Atl. Coast Line R., 147 S.E. 698, 700 (N.C. 1929); Atchison, T. \& S.F. Ry. v. Saxon, 21 S.W.2d 686, 689 (Tex. Civ. App. 1929). 
role that had been imposed by Congress initially-providing for appeals of right ${ }^{101}$ - but later changed to provide for discretionary review in 1916.102

The U.S. Supreme Court's first misstep in Rogers is its interpretation of the Missouri Supreme Court's decision as finding that the plaintiff's conduct in failing to keep a proper lookout and attend to the fire that he set was the "sole cause" of his injury. ${ }^{103}$ The basis for this understanding of the Missouri Supreme Court's opinion is its observation that the plaintiff brought the emergency on himself. ${ }^{104}$ But this observation is best understood as an explanation of the court's ruling that there was insufficient evidence of the defendant's negligence-a ground that required reversal of plaintiff's judgment. ${ }^{105}$ There was no basis-nor any need-to pin a sole proximate cause tag on the plaintiff's conduct. If the plaintiff was the sole proximate cause of the harm, then the defendant was not a proximate cause of the harm and there is a failure with regard to that prima facie element of the case. And if the defendant's negligence was a proximate cause, then the plaintiff's conduct cannot be the sole proximate cause. Moreover, the Missouri Supreme Court never used "sole cause" in its opinion. ${ }^{106}$ Finally, the "emergency brought about by himself" language was made in the midst of the court's discussion of the defendant's negligence, not in its consideration of proximate cause. ${ }^{107}$

The fascination with the sole proximate cause language in Rogers and other FELA cases appears, in part at least, to be an unfortunate artifact of the language in the statute, which imposes liability if the plaintiff's injury resulted, "in whole or in part," from the defendant's

101. See Felix Frankfurter \& James M. Landis, The Business of the Supreme Court: A Study in The Federal Judicial System 213 (1928) (explaining that the reasons for the change from mandatory review to discretionary review was "to save the Supreme Court from the voluminous futilities of employers' liability litigation").

102. Act of Sept. 6, $1916 \mathrm{ch} .448,39$ Stat. 726 (codified as amended at 28 U.S.C. $\$ 1257$ ). A portion of Justice Brennan's opinion is a lecture on Congress's intent in the FELA with regard to the role of the jury. See Rogers v. Mo. Pac. R.R., 352 U.S. 500, 508-10 (1957). Justice Brennan's opinion includes the claim that the Court has a role "when lower federal and state courts persistently deprive litigants of their right to a jury determination." Id. at 510 . That lecture is also an oblique response to the dissent of Justice Frankfurter, who lamented the error-correcting role that the Court had continued to pursue in FELA cases because of the lower courts' hair-trigger tendency to take cases away from the jury. See id. at 526 (Frankfurter, J., dissenting).

103. Id. at 504 (majority opinion).

104. Rogers, 284 S.W.2d at 472.

105. On no account was the plaintiff's conduct the sole factual cause-although it was a factual cause. The circumstances in Rogers were not such that either the defendant's negligence or the plaintiff's negligence, but not both, was a cause of the harm. See supra fig.2. Both plainly could have been a cause of the harm.

106. "[S]ole proximate cause" was used in the jury instruction. Rogers, 352 U.S. at 505.

107. Id. at 504 (quoting Rogers, 284 S.W.2d at 472). 
negligence. ${ }^{108}$ If that language is about proximate cause, and its structure suggests otherwise, ${ }^{109}$ then one way for the defendant to be exonerated is if someone else is the sole proximate cause. Presumably, then, the defendant's negligence played no part in the harm. As explained in Part II, the straightforward explanation of the outcome is that defendant's negligence was not a proximate cause of harm. ${ }^{110}$ The language of the FELA, moreover, would not change that conclusion; if the defendant's negligence was not a proximate cause of the harm, then the negligence played no part in it.

In addition to its finding of no negligence, the Missouri Supreme Court decided alternatively that any negligence by the defendant in maintaining the culvert was not a proximate cause of the plaintiff's harm. ${ }^{111}$ After explaining that the fire being swept by the train's draft and the necessity for the plaintiff to take evasive action with the fire upon him was "extraordinary," the court concluded "plaintiff's injury was not the natural and probable consequence of any negligence of defendant."112 Recall that the same natural and probable language was used by the court to explain the standard for proximate cause. ${ }^{113}$ The court may have been wrong in its proximate cause ruling, but it is not because it decided plaintiff was the sole proximate cause. ${ }^{114}$

Justice Brennan next attended to the final passage in the Missouri Supreme Court's opinion, providing its third ground-lack of proximate cause-for reversing plaintiff's judgment:

And if there was negligence in failing to maintain a sufficiently wide path across the culvert or in permitting that path to become covered with crushed rock or gravel, still plaintiff's evidence is completely lacking in probative facts supporting a conclusion that defendant's negligence, in whole or in part, contributed to plaintiff's injury. ${ }^{115}$

Justice Brennan interpreted this language as concluding that the plaintiff's conduct was at least as probable a cause of the injury as the negligence of the defendant. That interpretation would only be ap-

108. 45 U.S.C. $\S 51$ (2006).

109. See infra text accompanying notes $115-26$.

110. See supra notes 74-79 and accompanying text.

111. Rogers, 284 S.W.2d at 470-72. The proximate cause aspect of the court's decision might be read as an alternative ground to the court's finding insufficient evidence of any negligence by defendant.

112. $I d$. at 472 .

113. Id. at $471-72$.

114. The trial court's use of sole proximate cause with regard to the plaintiff's negligence in its instructions ran afoul of Congress's adoption of comparative fault for FELA actions. See Act of Apr. 22, 1908, ch. 149, 35 Stat. 65, 66 (codified at 45 U.S.C. $\$$ 53). But that error was harmless, as the jury returned a verdict for the plaintiff. Thus, instructional error was not before the Supreme Court in Rogers.

115. Rogers, 284 S.W.2d at 472. 
propriate if the plaintiff's and the defendant's conduct were mutually exclusive competing causes, as in Figure 2, supra. The difficulty with that interpretation is that there was no dispute on this matter-no one contended that the situation was such that either the plaintiff's or the defendant's negligence was the factual cause of harm, but not both. Deciding that the defendant's negligence was a factual cause of the harm did not rule out that the plaintiff's conduct was also a factual cause and vice versa. Thus, this was not a case in which either the defendant or the plaintiff was the cause of the fall, as was, for example, the case in the classic Summers v. Tice, in which only one of the two hunters fired the bullet that did the predominant damage to the plaintiff. ${ }^{116}$ That being the case, Justice Brennan's treatment of which cause was more probable presented a false dilemma: the conduct of both actors could have been causes. ${ }^{117}$ With this incorrect factual model, it is not surprising that Justice Brennan reached an illogical conclusion: the Missouri Supreme Court's more-probable-cause standard would require that the jury rule out any causes-the plaintiff's negligence-other than the defendant's negligence. On the contrary, in a situation such as Rogers, as illustrated in Figure 1, in which both the plaintiff's and the defendant's conduct could have been a cause of the harm, there is no need to rule out one to conclude that the other is also a cause. Yes, in a Summers-type case, as illustrated in Figure 2, the fact finder must decide which is more probable and that necessarily eliminates the alternative potential cause, but that was not the circumstance in Rogers.

Justice Brennan's next error was even more egregious than the two described above, followed from the illogical conclusion explained above, and led to the "any part, even the slightest" declaration. ${ }^{118}$ Quoting the Missouri Supreme Court's statement of the standard for

116. 199 P.2d 1, 2-3 (Cal. 1948).

117. Nor was the question whether the plaintiff's burden of persuasion is something less than the standard of preponderance of the evidence. It appears well established that the FELA requires the same burden of proof as in most civil cases, a preponderance of the evidence. See, e.g., Seventh Circuit Federal Jury Instruction 9.01 (2010); Wright v. Ark. \& Mo. R.R., 574 F.3d 612, 616 n.5 (8th Cir. 2009); Wilson v. Chi., Milwaukee, St. Paul, \& Pac. R.R., 841 F.2d 1347, 1353 (7th Cir. 1988); see also Martin v. Harris, 560 F.3d 210, 216 (4th Cir. 2009) (Jones Act case); Richardson v. Mo. Pac. R.R., 186 F.3d 1273, 1279 (10th Cir. 1999) (Boiler Inspection Act case); Kavorkian v. CSX Transp., Inc., 117 F.3d 953, 956 (6th Cir. 1997). That is so notwithstanding the more lenient standard for the burden of production. See, e.g., Howard v. Can. Nat' $1 / 111$. Cent. R.R., 233 F. App'x 356, 357 (5th Cir. 2007) (characterizing the burden of production as "featherweight"); Tufariello v. Long Island R.R., 458 F.3d 80, 87 (2d Cir. 2006) ("[T]he plaintiff's burden in making a showing of causation and negligence is lighter under FELA than it would be at common law."); Estate of Larkins v. Farrell Lines, Inc., 806 F.2d 510, 512 (4th Cir. 1986) (characterizing the burden of proof under the FELA as "light").

118. Rogers v. Mo. Pac. R.R., 352 U.S. 500, 506 (1957). 
factual causation, "but for" and "absent the negligent act," the Court characterized it as "language of proximate causation," which it most surely was not. ${ }^{119}$ This language, as interpreted by the Court, required that the evidence permit a conclusion "that the defendant's negligence was the sole, efficient, producing cause of injury." 120 We might evaluate sympathetically Justice Brennan's incorrect characterization of the Missouri Supreme Court's language as addressing proximate cause by recognizing the loose, conflicting, and confusing usage of proximate cause. But the second aspect of his interpretation-with regard to "sole cause"-is more troubling; the but-for standard surely does not imply a requirement that only one cause exists. Quite to the contrary, the but-for test is such that many necessary conditions can exist.

All of this was the immediate prelude to the Rogers Court announcing its "any part, even the slightest, in producing the injury"121 rule that has dominated causal consideration in FELA cases for the last half century. ${ }^{122}$ The Court also seemed to conflate the substantive any-part standard for causation with the burden of proof, warning that whether other probabilities exist is irrelevant once the any-part standard is met. ${ }^{123}$ Indeed, the Court's opinion provides additional evidence in three places that the "any part, even the slightest" language is about the burden of production. The context for the phrase was significant introductory language: "the test of a jury case is simply whether the proofs justify with reason the conclusion that employer negligence played any part, even the slightest, in producing the injury ...."124 "[T] $]$ he test of a jury case" surely sounds as if it is addressed to judges when considering whether there is sufficient evidence to submit the issue to the jury. Yet in the very next paragraph, the Court suggests that the language is about a plaintiff's prima facie case. ${ }^{125}$ Explaining that many aspects of common law torts had been stripped away in the FELA because of its reformist purposes, the Court con-

119. Id. (quoting Rogers, 284 S.W.2d at 471).

120. Id. (quoting Rogers, 284 S.W.2d at 471).

121. Id. A paragraph later, Justice Brennan reiterated, in a slightly different formulation, that the issue is whether employer negligence "played any part, however small, in the injury." Id. at 508 .

122. A Westlaw search in the ALLCASES directory for this language produced 638 cases from 1956, when Rogers was decided, until November 17, 2011.

123. Does that mean that, even if the overwhelming probability is that a competing cause was responsible for the plaintiff's harm, so long as there is any probability that it was the defendant's negligence, the case must go to the jury? If so, then "any part" has morphed into being about the burden of persuasion rather than causation.

124. Rogers, 352 U.S. at 506.

125. See id. at 508 ("The burden of the employee is met, and the obligation of the employer to pay damages arises, when there is proof, even though entirely circumstantial, from which the jury may with reason make that inference."). 
cluded that FELA cases present only "the single question whether negligence of the employer played any part, however small, in the injury or death which is the subject of the suit."126

With largely inscrutable statutory language, a purpose to provide injured railroad employees more comprehensive coverage for their occupational injuries, albeit one wrapped within a fault-based tort system, addled treatment of causation and inconsistent signals about what the statutory language meant in Rogers, we should not be surprised that the aftermath of Rogers has been a half century of muddle about factual cause, scope of liability, the burden of production, ${ }^{127}$ and the relationship of these concepts in FELA jurisprudence. As a California court observed while struggling to make sense of the statutory language in light of Rogers, "The terminology "in whole or in part' is not the language of common law proximate cause, as the Supreme Court in Rogers emphasized." 128

Yes, but then what does the statutory language mean and what are the implications for FELA cases once that meaning is determined? Is the language about factual cause, and if so, what standard might it be adopting? Or is Rogers about the procedural matters of burden of production? Does the apparent lack of any language imposing limits on the scope of liability mean there are none? Or is there room in the statute and Rogers's interpretation of it for both factual causation and scope of liability?

\section{A. Factual Causation}

Perhaps Rogers's interpretive gloss, "any part, even the slightest," is about factual causation. ${ }^{129}$ First, note the syntactical disconnect created by the Court's insertion of "even the slightest." 130 But-for causes

126. Id. at 508 .

127. Some courts explain Rogers as addressing the burden of production. See, e.g., Bertrand v. S. Pac. Co., 282 F.2d 569, 573 (9th Cir. 1960) ("The court in [Rogers], however, was not speaking of 'the test of liability of the railroad carrier' (the language used in the proposed instruction) but 'the test of a jury case.' If the proofs justify with reason the conclusion that employer negligence played any part, 'even the slightest,' in producing the injury or death, then the issue of causal relation must go to the jury."). A Fifth Circuit case explains Rogers as being more about "the sufficiency of evidence of causal connection to require submission of the issue to a jury than upon the propriety of particular instructions as to proximate cause." Page v. St. Louis Sw. Ry., 312 F.2d 84, 90 (5th Cir. 1963). If that is so, then there still remains the question of what is the standard for factual causation and for scope of liability?

128. Parker v. Atchison, Topeka \& Santa Fe Ry., 70 Cal. Rptr. 8, 11 (Cal. Ct. App. 1968).

129. Norfolk \& Western Railway Co. v. Ayers unselfconsciously treats this language as addressing the factual cause aspect of the FELA. See 538 U.S. 135, 161-62 (2003); see also Clark v. Kellogg Brown \& Root L.L.C., 414 F. App'x 623, 626 (5th Cir. 2011) (employing the Rogers standard as a factual cause standard).

130. Rogers, 352 U.S. at 506. 
are not slight, nor are they strong, medium, or any other matter of degree. Either they are or they are not necessary conditions for the outcome, full stop. Each, of course, is a necessary condition, which tort law recognizes by requiring only that tortious conduct be $a$ cause of harm, rather than the cause of harm. ${ }^{131}$ Can negligence play a part-no matter how small-in causing harm without being necessary for the outcome? I do not know how, and I can only speculate about how a jury would understand that language in comparison to an instruction that stated the defendant's negligence is a cause if the plaintiff's harm would not have occurred in the absence of the negligent conduct.

At its most absurd, that interpretation could result in liability divorced from factual causation-all injured railroad workers could sue all negligent railroads, regardless of the relationship between the negligence and the harm. How could the Court avoid that absurd result but give some meaning to language that may be designed to dilute the common law element of factual causation?

Less preposterous than eliminating factual cause, but still unlikely, it might mean that so long as the defendant's negligence creates a risk of the sort of harm suffered by the plaintiff, in the absence of evidence negating factual cause, the "in whole or in part" element is satisfied. ${ }^{132}$ That would effectively shift the burden of proof to defendants on factual cause, and of course, the burden of proof has particular bite when there is a paucity of evidence on the matter.

Perhaps "in whole or in part" means something somewhat different from sine qua non causation-an issue that arises most prominently in disease cases when multiple risk factors exist and the one that actually caused the harm cannot be identified in light of available scientific understanding. This is the case with asbestotic diseases, which have been the basis for FELA actions for some years. ${ }^{133}$ "[I]n whole or in part" might refer to the risk contribution of the defendant's toxic agent, thereby obviating the need to prove the unprovable-which asbestos fiber or fibers were responsible for the plaintiff's disease. ${ }^{134}$ While risk contribution is a coherent explanation for the "in whole or in part" language, it surely could not have been what Congress meant

131. See Restatement (Third) of Torts: Liab. for Physical \& Emotional Harm $§ 26$ cmt. c (2010).

132. 45 U.S.C. $\$ 51$ (2006).

133. For elaboration, see Michael D. Green, A Future for Asbestos Apportionment?, 12 ConN. INS. L.J. 315 (2006) (explaining uncertainties about which defendant's conduct played a causal role in the existence or severity of plaintiff's asbestotic disease); Michael Green, Second Thoughts About Apportionment in Asbestos Litigation, 37 Sw. U. L. REv. 531 (2008).

134. See Rutherford v. Owens-Ill., Inc., 941 P.2d 1203 (Cal. 1997). 
in 1908, half a century or more from tort law confronting disease cases involving asbestos, radiation, cigarette smoking, and pharmaceuticals.

The risk-contribution concept could be applied to traumatic injury as well. So long as the defendant's negligence increases the risk of harm that the plaintiff suffered-and it cannot be ruled out as the cause of the harm-then characterizing its role as having played a part in producing the injury does not offend the language in Rogers. ${ }^{135}$ The statutory language, however, which uses the word "resulting" to connect the injury to the negligence, ${ }^{136}$ leans more heavily toward causation (as opposed to risk contribution) than does the interpretive language in Rogers of the negligence having "played any part" in the injury. ${ }^{137}$ Risk can play a part, but injury does not result from risk unless the other elements sufficient for harm to occur are present.

Perhaps "in whole or in part" means that other culpable causes are irrelevant to a railroad's liability, so long as its negligence is a factual cause of harm? ${ }^{138}$ That meaning is benign because that result would occur anyway. That a different person's tortious conduct is also a cause of the plaintiff's harm does not obviate the causal role of others, ${ }^{139}$ save for the limited instance described above. ${ }^{140}$ Moreover, Congress made explicit in $\S 3$ of the FELA that a plaintiff's contributory negligence "shall not bar a recovery, but the damages shall be diminished by the jury in proportion to the amount of negligence attributable to such employee." ${ }^{141}$ But if this were its meaning, the Rogers's "even the slightest" gloss is curious. As explained in Part II, negligence may be slight (in relation to another party's culpable conduct) but factual causes cannot be compared. ${ }^{142}$

135. Judge Calabresi pursued this approach in Zuchowicz v. United States, with his recharacterization of Martin v. Herzog, 126 N.E. 814 (N.Y. 1920). 140 F.3d 381, 391 (2d Cir. 1998) ("It follows that when a negative side effect is demonstrated to be the result of a drug, and the drug was wrongly prescribed in an unapproved and excessive dosage (i.e. a strong causal link has been shown), the plaintiff who is injured has generally shown enough to permit the finder of fact to conclude that the excessive dosage was a substantial factor in producing the harm."). But he beat a hasty retreat in Williams v. Utica College of Syracuse University, 453 F.3d 112, 120-21 (2d Cir. 2006).

136. 45 U.S.C. \& 51.

137. Rogers v. Mo. Pac. R.R., 352 U.S. 500, 506 (1957).

138. A variation of this idea is that the statutory language was meant to abrogate the last wrongdoer rule. See supra notes 29-34 and accompanying text. This seems implausible, as the rule had largely died out by the time the FELA was enacted. In any case, this meaning would be benign and redundant for the same reason as explained in the text.

139. Yes, it might on the grounds that the other party's tortious conduct is a superseding cause of harm. But that is not a factual cause doctrine but rather one of scope of liability.

140. See supra note 47 , fig.2, and accompanying text.

141. Act of Apr. 22, 1908 ch. 149, 35 Stat. 65,66 (codified at 45 U.S.C. $\$ 53$ ).

142. See supra notes $50-51$ and accompanying text. 
Most courts do not trouble to ask the questions posed above about factual causation; instead they endorse the Rogers language for use in jury instructions and duck out of the way. ${ }^{143}$ The effect of this is to leave the jury without any meaningful standard for deciding causation and to fail to inform the jury that, before the defendant can be held liable, the jury must find that the plaintiff's harm would not have occurred if the defendant had acted nonnegligently. Tortious acts ${ }^{144}$ are not any part of an outcome-in a factual causation sense-unless they are necessary for its occurrence. The "in whole or in part" jury instruction leaves the jury with no explanation of factual causation.

\section{B. Burden of Production}

Or is Rogers merely about the burden of production (or legal sufficiency of the evidence) that the plaintiff must satisfy to establish the factual cause element of an FELA case? ${ }^{145}$ Or negligence? In two senses, this is a more attractive interpretation of Rogers than the factual causation alternative suggested above. First, as explained above, the Missouri Supreme Court ruled on burden of production grounds both with regard to negligence and factual causation, albeit in quite different respects. The ruling that the defendant did not act negligently was made not because the plaintiff failed to introduce sufficient evidence of negligence (although that was not what the court said), but because the court felt that, on the facts, no reasonable jury could find that the defendant acted unreasonably. ${ }^{146}$ The alternative ruling on factual causation, however, is based on the plaintiff providing insufficient evidence to connect causally the negligence of the railroad in maintaining the condition of the culvert with the plaintiff's injury. ${ }^{147}$

Second, Rogers was motivated by the then-common practice of courts to remove cases from the jury on sufficiency of the evidence grounds. Having Rogers move the line between reasonable inference and impermissible speculation would address what was the driving

143. See, e.g., Summers v. Mo. Pac. R.R. Sys., 132 F.3d 599 (10th Cir. 1997); Hausrath v. N.Y Cent. R.R., 401 F.2d 634, 636-37 (6th Cir. 1968); DeLima v. Trinidad Corp., 302 F.2d 585 (2d Cir. 1962); Hoyt v. Cent. R.R., 243 F.2d 840, 843 (3d Cir. 1957).

144. See supra notes 50-52 and accompanying text.

145. See, e.g., Holbrook v. Norfolk S. Ry., 414 F.3d 739 (7th Cir. 2005); Ulfik v. Metro-N. Commuter R.R., 77 F.3d 54, 58 (2d Cir. 1996).

146. Rogers v. Thompson, 284 S.W.2d 467, 472 (Mo. 1955); see also Lo Cicero v. Columbia Cas. Co., 268 F.2d 440, 441 (5th Cir. 1959) (finding that the jury should have been instructed that the police officer's failure to sound the siren while proceeding to the crime scene was negligent as a matter of law).

147. Rogers, 284 S.W.2d at 472. 
motivation behind that opinion. Moreover, that is what the Court said it was doing in Rogers: "This Court granted certiorari to consider the question whether the decision [of the Missouri Supreme Court] invaded the jury's function." 148

There are, however, several difficulties with this interpretation. First, when the Court wanted to address the issue of legal sufficiency, it had previously demonstrated that it could say so in clear, unambiguous terms. ${ }^{149}$ Second, finding the standard for sufficiency of the evidence in statutory language is odd. Legal sufficiency is a procedural common law standard that rarely is addressed in positive law. And if contrary to this, Congress did mean to address sufficiency of the evidence in the language of the FELA, employing the "in whole or in part" language was an unorthodox and mystifying way to do so.

\section{Scope of Liability}

Does Rogers or the FELA modify common law scope of liability limitations? That question is particularly tricky to answer for three reasons. First, the Supreme Court has stated that the FELA adopted the common law framework for tort actions except to the extent specifically addressed in the statute. Thus, even if the "in whole or in part" language does not include a scope of liability element, there may nevertheless be one from the common law wraparound for the FELA. But that raises the question of whether the statutory language includes both a factual cause and scope of liability element. Here, the second difficulty arises: the nonstandard language in the statute, combined with customary umbrella coverage of factual cause and scope of liability at the time the FELA was enacted, creates a difficult interpretive puzzle. Finally, Congress has a penchant for enacting legislation providing a private right of action that contains no mention of proximate cause or other scope of liability limits. The Court has, on a number of occasions, ministered to that omission by reading such a limitation into the statute. ${ }^{150}$

A number of courts have interpreted Rogers as having adopted a less rigorous, or even eliminating any, scope of liability limitation from the statute. ${ }^{151}$ Coray v. Southern Pacific Co., a pre-Rogers deci-

148. Rogers v. Mo. Pac. R.R., 352 U.S. 500, 501 (1957).

149. See, e.g., Lavender v. Kurn, 327 U.S. 645, 652-53 (1946).

150. See infra notes $126-57$ and accompanying text.

151. See, e.g., Oglesby v. S. Pac. Transp. Co., 6 F.3d 603, 607 (9th Cir. 1993) (stating that the "any part, even the slightest" language in Rogers "has been read to indicate that common law 'proximate cause' is not required under the FELA"). Compare Ulfik v. Metro-N. Commuter R.R., 77 F.3d 54, 58 (2d Cir. 1996) (concluding that scope of liability under the FELA permits liability when it would not exist at common law), with Nicholson v. Erie R.R., 253 F.2d 939, 
sion, supports that conclusion. ${ }^{152}$ The plaintiff's decedent was killed when a train he was following in a one-man motorcar stopped suddenly due to defective brakes, and the decedent did not stop the motorcar before it crashed into the train. ${ }^{153}$ The train's defective brakes violated a federal safety standard, thus establishing the defendant's negligence. ${ }^{154}$ The trial court ruled that the purpose of the statute was not to protect those following a train and directed a verdict for the defendant, ${ }^{155}$ which the state supreme court affirmed. ${ }^{156}$ The U.S. Supreme Court reversed with sweeping language that suggested that statutory purpose (the negligence per se equivalent of scope of liability) was to play no role for statutory violations: "this Act, fairly interpreted, must be held to protect all who need protection from dangerous results due to maintenance or operation of congressionally prohibited defective appliances." 157 Two years after Rogers, Justice Brennan reaffirmed Coray and proceeded in dicta to extend it to cases in which fault was based on the general negligence standard.

Among the refinements developed by the common law for the purpose of limiting the risk of liability arising from wrongful conduct is the rule that violation of a statutory duty creates liability only when the statute was intended to protect those in the position of the plaintiff from the type of injury in fact incurred. This limiting approach has long been discarded from the FELA. Instead, the theory of the FELA is that where the employer's conduct falls short of the high standard required of him by this Act, and his fault, in whole or in part, causes injury, liability ensues. And this result follows whether the fault is a violation of a statutory duty or the more general duty of acting with care, for the employer owes the employee, as much as the duty of acting with care, the duty of complying with his statutory obligations. ${ }^{158}$

One might be concerned (in light of the hypothetical fate of Eve referred to above) about virtually limitless liability for railroads under the FELA. For two reasons, I do not think that an absence of any scope of liability limitation is quite that dire. First, the plaintiffs who can sue are limited to railroad employees. ${ }^{159}$ That means that cascad-

940-41 (2d Cir. 1958) (affirming the dismissal of the complaint on conventional common law scope of liability grounds).

152. 335 U.S. 520 (1949).

153. Id. at $522-23$.

154. Id. at 523 .

155. Id. at 522 .

156. Id.

157. Id. at 522-23.

158. Kernan v. Am. Dredging Co., 355 U.S. 426, 438-39 (1958).

159. See 45 U.S.C. $\S 51$ (2006) ("[Railroad] shall be liable in damages to any person suffering injury while he is employed by such carrier ...."). 
ing chains of harm that might be visited on others are eliminated from consideration by this limitation to the FELA. Second, frequently the claims of negligence in the FELA are quite general-failing to provide a safe workplace or safe equipment, or failing to adopt workplace rules that would ensure safety. ${ }^{160}$ With negligence specifications like these, almost any occupational injury is within the scope of liability if a harm-within-the-risk test or a foreseeability standard were employed. Norfolk Southern Railway Co. v. Sorrell illustrates this point. Sorrell involved an accident between two motor vehicles driven by railroad employees on railroad property. ${ }^{161}$ The two questions were whether the other driver was negligent and, if so, whether the plaintiff was also negligent. ${ }^{162}$ But the specification of defendant negligence was "Norfolk failed to provide him with a reasonably safe place to work." 163 With such a general claim of negligence, virtually any workplace injury is foreseeable or represents harm resulting from the risk created by the defendant's negligence. While the occasional case of coincidental harm-harm whose risk was not increased by the negligence of the defendant, such as in the classic Berry v. Sugar Notch Borough ${ }^{164}$-would go forward, eliminating scope of liability would not be nearly as great a calamity for the railroad industry as might otherwise appear.

On a broader level, giving cognizance to negligence claims such as failure to provide a safe workplace takes the FELA a long way from its tort analog toward a compensation system by diluting the requirement of employer fault.

Notwithstanding the inherent limitations in the FELA on scope of liability, the majority opinion in Sorrell provides evidence that there remains some role for scope of liability in the statute. In Sorrell, the Court held that the same causal standard applicable to defendant negligence was also applicable to plaintiff negligence. ${ }^{165}$ The Court reasoned that comparisons of the plaintiff and the defendant negligence necessary for the comparative scheme adopted in the FELA would be facilitated by having the same causal standard apply to both. ${ }^{166}$ But

160. See, e.g., Haischer v. CSX Transp., Inc., 848 A.2d 620, 624 (Md. 2004); Sinclair v. Burlington N. \& Santa Fe Ry., 200 P.3d 46, 51 (Mont. 2008); Deviney v. Union Pac. R., 786 N.W.2d 902, 905 (Neb. 2010).

161. 549 U.S. 158 (2007).

162. Id.

163. Id.

164. 43 A. 240 (Pa. 1899); see also Restatement (Third) of Torts: Liab. For Physical \& EMOTIONAL HARM $\S 30$ (2010) ("An actor is not liable for harm when the tortuous aspect of the actor's conduct was of a type that does not generally increase the risk of that harm.").

165. See 549 U.S. 158, 160 (2007).

166. $I d$. at $168-71$. 
factual cause, at least the but-for version, is not a matter of degree and cannot be a basis for comparison. Its only function for comparative purposes is to determine which parties' negligence is relevant (those that are a factual cause of the harm) and which parties' negligence is not (those that are not a factual cause). Scope of liability limitations, however, can be a matter of degree, as explained in Part II. ${ }^{167}$ Thus, Sorrell suggests that there is some scope of liability content to the statutory language.

By contrast, in a concurring opinion that some have hailed as returning rationality to interpretation of the FELA, Justice Souter read Rogers as not addressing scope of liability. ${ }^{168}$ Justice Souter's analysis, unfortunately, contains several flaws that render it implausible.

Justice Souter's reading of Rogers would enable the claim that the FELA incorporated the common law principles of tort that were a wraparound for the statutory language, including scope of liability. Rogers, in Justice Souter's view, only rejected the lower court's requirement that the defendant's negligence had to be the sole cause of the harm, ${ }^{169}$ a requirement, as explained above, that was a straw person for the Rogers Court, in that the Missouri Supreme Court held no such thing. ${ }^{170}$ Justice Souter's claim then proceeds to assert that Rogers only addressed the situation when there were multiple tortious causes of an injury and did not otherwise rule on appropriate scope of liability limits. ${ }^{171}$ However, if Rogers was only about the situation in which both the defendant and the plaintiff's negligence concur to cause harm, holding that each could satisfy the FELA's causation requirement, it was such a trivial decision that one wonders why anyone has paid any attention to it since. ${ }^{172}$ This interpretation also requires a conclusion that Congress gilded the lily in the FELA by employing the

167. See supra notes $69-71$ and accompanying text.

168. Sorrell, 549 U.S. at $174-75$ (Souter, J., concurring) ("Rogers left this law [referring to proximate cause as the proper standard in FELA suits] where it was.").

169. $I d$.

170. See supra notes $103-07$ and accompanying text.

171. Justice Souter made the same error as in Rogers, conflating the multiple causes of harm, see supra fig.1, with multiple competing causes of harm, see supra fig.2. See Sorrell, 549 U.S. at 175.

172. There are other difficulties with Justice Souter's opinion. He perpetuates the idea that factual cause can be fractionated, writing:

we held [in Rogers] that a FELA plaintiff may recover even when the defendant's action was a partial cause of injury but not the sole one. Recovery under the statute is possible, we said, even when an employer's contribution to injury was slight in relation to all other legally cognizable causes.

Sorrell, 549 U.S. at 175. And his attribution of the Rogers language, "any part, even the slightest," to speak to apportionment among parties is, well, just wrong. Id. There was no issue of apportionment raised in Rogers. 
"in whole or in part" language because $\S 3$ quite clearly stated that plaintiff's fault did not bar recovery but only reduced proportionally plaintiff's recovery. ${ }^{173}$

\section{The Effect of the Progressive Intent of the Statute on Its Interpretation}

Might not the progressive intent of the FELA to provide greater financial relief for the injury and death toll produced by railroads inform this interpretive matter and justify more liberalized standards for factual causation, scope of liability, or both?174 Justice Brennan made such a claim in Rogers, observing that the FELA was enacted to assist injured railroad workers before reiterating that the question is "whether negligence of the employer played any part, however small, in the [plaintiff's] injury." 175 Other cases have echoed the sentiment that interpretation of the statute should be influenced by its progressive purpose. ${ }^{176}$

Justice Souter also relied on the trial court's instruction in Rogers, which used the term "proximate cause" and required that plaintiff's harm was "directly" caused by defendant's negligence. Justice Souter found the Court's failure to take issue with this instruction to be an endorsement of it. Id. at 176. As with the absence of apportionment as an issue, there was no issue about the correctness of the instructions before the Court in Rogers; recall that certiorari was granted with regard to the sufficiency of the evidence. See supra note 148 and accompanying text. Moreover, the correctness of the instructions could not have been a basis for review because the plaintiff, who would have suffered prejudice if they were incorrect, prevailed at trial.

173. Pub. L. No. 60-100, 35 Stat. 65, 66 (codified at 45 U.S.C. $\$ 53$ (2006)). There is contemporary support for the conclusion that Congress used the "in whole or in part" language precisely to gild the lily. A number of courts stated that contributory negligence barred a claim if it was a cause of the harm in whole or in part. See, e.g., Gregg v. N. Pac. Ry., 94 P. 911, 914 (Wash. 1908); Lowrimore v. Palmer Mfg. Co., 38 S.E. 430, 437 (S.C. 1901); Cunningham v. Lyness, 236 Wis. 239, 248 (1867); Heightman v. Sammons, 107 S.W. 31, 32 (Mo. Ct. App. 1908). This language was meant to convey that plaintiff's negligence did not have to be the sole factual cause of the harm. Of course, that proposition was unnecessary given that contributory negligence only mattered when the defendant was also negligent.

174. The Supreme Court provided a more articulate formulation of the premise of this question in Sinkler v. Missouri Pacific Railroad Co.:

$[I] n$ interpreting the FELA, we need not depend upon common-law principles of liability. This statute, an avowed departure from the rules of the common law, was a response to the special needs of railroad workers who are daily exposed to the risks inherent in railroad work and are helpless to provide adequately for their own safety. The cost of human injury, an inescapable expense of railroading, must be borne by someone, and the FELA seeks to adjust that expense equitably between the worker and the carrier. The Senate Committee which reported the Act stated that it was designed to achieve the broad purpose of promoting "the welfare of both employer and employee, by adjusting the losses and injuries inseparable from industry and commerce to the strength of those who in the nature of the case ought to share the burden."

356 U.S. 326, 329-30 (1958) (citations omitted) (quoting S. REP. No. 60-460, at 3 (1908)).

175. Rogers v. Mo. Pac. R.R., 352 U.S. 500, 508 (1957).

176. See, e.g., Consol. Rail Corp. v. Gottshall, 512 U.S. 532, 555, 560-61 (1994); Hane v. Nat'l R.R. Passenger Corp., 110 F.3d 573, 574 (8th Cir. 1997). 
Good question but dubious answer. This inquiry fails to recognize an important fact of compensation schemes. Workers' compensation systems all contain a factual cause requirement. Indeed, all compensation schemes, just like all tort claims, have a factual cause requirement. ${ }^{177}$ The causal agent required for workers' compensation is employment rather than employer negligence, but factual causation there is. Injured employees go uncompensated with some frequency because they are unable to make the causal connection between employment and their injury or disease. ${ }^{178}$

Moreover, workers' compensation includes a scope of liability limitation as well. ${ }^{179}$ In addition to employment being a factual cause of harm, most states employ a scope of liability requirement that the employment increase the risk of harm. Thus, an employee assigned to shovel a short sidewalk, similar in length to what they might shovel at home, would not recover workers' compensation if injured while shoveling the employer's walk on scope of liability grounds. Some states have more lenient limits on liability, but all have their limits. ${ }^{180}$

\section{Conclusion}

How might the "in whole or in part" language incorporated into the FELA when it was enacted in 1908 sensibly be understood? Although not in widespread use, there was some usage of this phrase at the time in reference to a plaintiff's contributory negligence. The idea was that no matter how slight the plaintiff's negligence, it still constituted a complete bar to recovery. ${ }^{181}$ That usage is coherent and a reasonable account of how contributory negligence works. Comparative negli-

177. See Rabin, supra note 13 , at 22 .

178. See, e.g., King v. Vt. Am. Corp., 664 So. 2d 214, 217 (Ala. Civ. App. 1994); Liberty Nw. Ins. Corp. v. Spurgeon, 820 P.2d 851, 852 (Or. Ct. App. 1991).

179. See 1 arthur Larson \& Lex K. Larson, Larson's Workers' Compensation Law $\S 4.03$ (rev. ed. 2011) (explaining risks that cannot be determined to be purely employment or personal).

180. See id. $\S 3.05$ (explaining the most liberal causation requirement, one that requires only that employment put plaintiff in a position that permitted risk to cause harm).

181. Rietveld v. Wabash R., 105 N.W. 515,517 (lowa 1906) ("[T]he plaintiff's negligence must be such as contributes proximately to his injury; but, if it does so in whole or in part, in any manner or to any degree, there can be no recovery ...."); Zeratsky v. Chi., M. \& St. P. Ry., 123 N.W. 904, 907 (Wis. 1909) (applying a statute that adopted modified comparative fault, stating that recovery could be had when an injury was caused by the railroad's negligence in whole or greater part than the negligence of the plaintiff); Bolin v. Chi., St. P., M. \& O. Ry., 84 N.W. 446, 446 (Wis. 1900) ("In an action to recover damages claimed to have been caused by actionable negligence of the defendant, contributory negligence of the plaintiff, however slight, precludes his recovering damages, notwithstanding negligence of the defendant, however great, contributed thereto."); Potter v. Chi. \& Nw. Ry., 21 Wis. 377, 382 (1867) ("Negligence, proximate or contributing to the injury, however slight, prevents recovery."). 
gence reveals that we can, and do, assess negligence or culpability on a spectrum and that, at least in comparison to others', a plaintiff's contributory negligence may be slight or whole, although the latter usage implies no negligence by the defendant. ${ }^{182}$ To be sure, there was a substantial body of case law that used "in whole or in part" in a similar head-scratching manner to Rogers. ${ }^{183}$ However, if we are trying to determine the best meaning for a statute, I do not know why, as an interpretive matter, we would feel bound to take such usage into account. But finding a coherent meaning for "in whole or in part" with regard to a plaintiff's contributory negligence is of no assistance in how to interpret its meaning in the FELA, where it cannot have that meaning. Recall that the FELA replaced contributory negligence with comparative fault, so that slight negligence by a plaintiff did not bar his claim. Equally tellingly, the "in whole or in part" language does not address the plaintiff's contributory negligence, but rather addresses the relationship between the defendant's negligence and the plaintiff's harm.

One might have hoped that CSX Transportation, Inc. v. McBride, ${ }^{184}$ a case recently decided by the Supreme Court, would clear away much of the confused underbrush left by Rogers and clarify a number of aspects about causation under the FELA. A list of aspirations for what McBride might have accomplished include the following. First, the Court might have insisted that factual causation be distinguished from scope of liability in thought, vocabulary, and jury instructions. Along with this conceptual clarification, terminologically, proximate cause might have been jettisoned from the FELA lexicon.

Second, the Court might have made plain that the plaintiff has the burden of proof to establish that the defendant's negligence was a necessary condition/but for/without which/sine qua non (take your pick) of the plaintiff's harm. Whatever "in whole or in part" means, it cannot mean something less than this connection between negligence and harm. Ameliorative doctrines may be developed when proof is not

182. Similarly, the term could be used coherently to address whether the fault of one of multiple defendants was sufficient to subject that defendant to liability but that usage was considerably less common.

183. See, e.g., Cooper v. Ga., C. N. Ry., 39 S.E. 543, 545 (S.C. 1901) ("[C]ontributory negligence must have in it the element of being a proximate cause, - not a remote cause, but a proximate cause from which the accident or injury, in whole or in part, directly and immediately resulted ...."); Rosevear v. Borough of Osceola Mills, 32 A. 548, 552 (Pa. 1895) ("[Plaintiff] can recover if her present condition, either in whole or in part, is the proximate result of [the] injury."); N.Y., Chi. \& St. L. R.R. v. Perigeuy, 37 N.E. 976, 977 (Ind. 1894) ("Negligence is contributory when, and only when, it directly and proximately induces the injury, in whole or in part." (quoting Bostwick v. Minn. \& P. Ry., 51 N.W. 781, 785 (N.D. 1892))).

184. 131 S. Ct. 2630 (2011). 
readily or practically available to the plaintiff, including shifting the burden of proof or employing risk contribution instead of factual causation, but those ameliorative devices would be limited to cases in which the circumstances warrant the use of these doctrines.

Third, we could hope that the Court would decide whether, within the FELA's statutory language, there is room for some scope of liability limitation on a defendant's liability. This is a common problem because legislators frequently omit any language addressing this issue, requiring some backfilling by courts, as the Supreme Court has done for other federal statutes. ${ }^{185}$ If the Court decided that some limitation applies, it should then identify which one of the extant standards should be used. At the same time, it should put in a permanent resting place the empty language that has littered the proximate cause landscape since the concept first emerged in tort law. ${ }^{186}$ The Court, then, would have been free to effectuate both the purpose of the FELA and the "in whole or in part" statutory language and to modify and diminish the common law scope of liability standard, thereby extending liability for negligently caused harm to a broader range of harms than would be permitted under the common law standard.

Finally, the Court might have confronted and resolved the effect of the "in whole or in part" language on the burden of production with regard to factual cause. I focus on the burden of production because it is entirely plausible, at least to me, that what Congress (and the Supreme Court in Rogers) meant to do was to ease the burden of proof for injured railroad workers in cases in which the factual causal connection between employer negligence and employee harm was uncertain. Those cases required deeper inferences than courts at the time permitted juries to draw, resulting in a ruling as a matter of law with the explanation that any determination of causation would have entailed impermissible speculation by the jury.

That is an expansive wish list for one case to accomplish. But these goals were not out of reach, and leaving the FELA and lower courts that regularly deal with it a clear conceptual structure was more than overdue after over a half century of Rogers's difficulties.

The defendant in McBride, who had suffered an adverse judgment, claimed that Rogers did not address whether scope of liability was a necessary element of an FELA claim. ${ }^{187}$ Instead, picking up on the

185. See, e.g., Dura Pharm., Inc. v. Broudo, 544 U.S. 336, 342-46 (2005) (securities fraud); Holmes v. Sec. Investor Prot. Corp., 503 U.S. 258, 265-68 (1992) (RICO); Associated Gen. Contractors of Cal., Inc. v. Cal. State Council of Carpenters, 459 U.S. 519, 529-35 (1983) (antitrust). 186. See supra notes $26-28$ and accompanying text.

187. See McBride, 131 S. Ct. at 2633. 
suggestion of Justice Souter in Sorrell, the defendant argued that Rogers was only about cases in which there were multiple tortious (including the plaintiff's) acts. ${ }^{188}$ Thus, the defendant argued that the Court should rule that proximate cause was an element of an FELA claim and that the failure to instruct the jury on proximate cause was erroneous. ${ }^{189}$ The court of appeals held that the instruction employed, a paraphrase of language from Rogers, was correct and affirmed the plaintiff's judgment. ${ }^{190}$

Thus, unfortunately, the way the issue was framed in the Supreme Court entailed parsing Rogers to determine whether it addressed and resolved the existence of a scope of liability requirement and, if so, its content. Both the majority and dissent fell for the bait, and both attempted to read and interpret Rogers to support their conflicting views. The majority, in an opinion by Justice Ginsburg, rejected the defendant's claim that Rogers and its "played any part, even the slightest" language did not address scope of liability and concluded that that language, without supplementation about any scope of liability limitation, was proper to employ in jury instructions in FELA cases. ${ }^{191}$ In the course of doing so, Justice Ginsburg perpetuated much of Justice Brennan's erroneous attribution of what the Missouri Supreme Court did in Rogers and engaged in the same conflation of the burden of production and scope of liability. ${ }^{192}$

Justice Ginsburg did accomplish several of the goals set out above, criticizing much of the language that has been used as a test of proximate cause and explaining that the term itself is confusing to jurors. ${ }^{193}$ In sanctioning the jury instruction employed by the lower court, both

188. See id. at 2637.

189. Defendant argued for different versions of language to be used in jury instructions. See id. at 2635 .

190. Id. at $2635-36$.

191. Id. at 2641 .

192. Justice Roberts, in dissent, claiming that Rogers was only about the role of plaintiff's fault in relation to defendant's fault, had to read into the Rogers's opinion resolution of several issues that just did not arise in the Missouri Supreme Court's opinion, but that the Supreme Court addressed (1) that plaintiff's conduct was the sole cause of harm; (2) that "cause" in FELA cases is not limited to a single or last cause; and (3) that Rogers involved a causal situation where only one of two alternative potential causes was the actual cause (like Figure 2). He was also cornered into reiterating Justice Souter's implausible theory about what Rogers decided and why Congress employed the "in whole or in part" language in the FELA. See also supra notes 168-72 and accompanying text.

193. McBride, $131 \mathrm{~S}$. Ct. at 2642 . But this portion of her opinion did not express a majority view as Justice Thomas, without opinion or explanation, failed to join this section of the 5-4 majority opinion. Id. at 2634 . The dissent was oblivious to terminology, advocating a "proximate cause" requirement for FELA cases and suggesting, among others, a "natural or probable consequence" test. Id. at 2652 (Roberts, C.J., dissenting). 
proximate cause and its unfortunate linguistic explanations have been banished from the FELA. ${ }^{194}$ The Court also adopted a limitation on the scope of liability, but in an unsatisfying manner.

The scope of liability limitation adopted by Justice Ginsburg is one about which the jury will not be instructed. Instead, she wrote that with instructions on negligence and causation, jurors, using their common sense, "would have no warrant to award damages in far out 'but for' scenarios." 195 Citing approvingly at least one case in which a court ruled as a matter of law that scope of liability was absent, the majority reintroduced a scope of liability requirement that will be enforced by judges as a matter of law. Those courts at least will have the vague guidance to avoid "far out" factual scenarios, ${ }^{196}$ but jurors would have to divine this from a "played a part-no matter how small" (or similar) instruction. ${ }^{197}$

194. The dissent not only embraced proximate cause terminology, but also inadvertently provided an object lesson in why it should be discarded. In the course of arguing that, before Rog. ers, the Supreme Court had understood that proximate cause was an FELA requirement, the dissent cited several cases that stated or implied "proximate cause" was an element. Id. at 2647-48 (Roberts, C.J., dissenting). The difficulty is that in at least some of them it is unclear whether the Court was referring to scope of liability or factual cause. Id. (citing and quoting Carter v. Atlanta \& St. Andrews Bay Ry., 338 U.S. 430, 435 (1949) ("[I]f the jury determines that the defendant's breach is a 'contributory proximate cause' of injury, it may find for the plaintiff."); O’Donnell v. Elgin, Joliet \& E. Ry. Co., 338 U.S. 384, 394 (1949) ("[P]laintiff was entitled to $\mathrm{a}[\mathrm{n}]$... instruction ... which rendered defendant liable for injuries proximately resulting therefrom.")).

Even worse, while mustering state courts that agree that proximate cause is required for FELA liability, the dissent cites a case in which it is clear that what the court meant was factual cause and not scope of liability. See id. at 2650 (citing and quoting Gardner v. CSX Transp., Inc., 498 S.E.2d 473, 483 (W. Va. 1997)). In addition, while criticizing the majority for its discussion of reasonable foreseeability as a limit on FELA liability-because foreseeability of harm is initially a matter bearing on negligence-the dissent cited a case in support of its proposition that discusses reasonable foreseeability in the same context. See id. (citing and quoting Marazzato v. Burlington N. R.R., 817 P.2d 672, 675 (Mont. 1991)).

195. McBride, $131 \mathrm{~S}$. Ct. at 2643.

196. "Far out 'but for' scenarios" is a less than optimal scope of liability standard, in any case. Harm may occur due to an unusual concatenation of events, but if the harm is reasonably foreseeable or it results from the risks that made the defendant negligent, liability should follow. See Derdiarian v. Felix Contracting Corp., 414 N.E.2d 666, 670 (N.Y. 1980); Restatement (ThIRD) of Torts: Liab. for Physical \& Emotional Harm $\$ 29 \mathrm{cmt}$. o (2010).

197. The dissent, appropriately in my view, criticized this aspect of the majority opinion, along with its treatment of foreseeability, explained in the next paragraph of the text:

In one respect the Court's test is needlessly rigid. If courts must instruct juries on foreseeability as an aspect of negligence, why not instruct them on foreseeability as an aspect of causation? And if the jury is simply supposed to intuit that there should also be limits on the legal chain of causation-and that "but for" cause is not enough-why hide the ball? Why not simply tell the jury? Finally, if the Court intends "foreseeability of harm" to be a kind of poorman's proximate cause, then where does the Court find that requirement in the test Rogers-or FELA-prescribes? Could it be derived from the common law? 
Finally, suggesting that the requirement that foreseeability exist for negligence to be established somehow assists in limiting the scope of liability nourishes confusion and encourages collapsing different doctrinal elements. The foreseeability that is required for a finding of negligence is a separate matter from foreseeability as a limit on scope of liability. It may be entirely foreseeable that defective brakes on a locomotive would result in a train crash (and thereby support a finding of railroad negligence) but unforeseeable that an employee would be bitten by a tsetse fly after alighting from the train once it finally was stopped (thereby supporting a conclusion that plaintiff's harm was outside the scope of defendant's liability). ${ }^{198}$

Most of the rest of the scorecard above remains unfulfilled. Insisting on the language of Rogers for jury instructions, Justice Ginsburg neglected to explain its relationship with the but-for standard for factual causation. ${ }^{199}$ Thus, a jury might decide that, although it is not persuaded the plaintiff's harm would have occurred in the absence of the defendant's negligence, it nevertheless played a "small part" in that harm. And I believe a court, consistent with McBride, should not disturb that determination, although I am not sure how it would be aware of such a circumstance. Finally, the majority said nothing about the burden of production on factual cause, but criticism on that failure may not be fair as the sufficiency of the evidence for factual cause was not an issue in McBride.

Thus, in an important sense, $M c B r i d e$ remains true to the animus in Rogers. It leaves the jury with a great deal of decision making authority in FELA cases-surely more than in common law tort cases. It is unfortunate that it accomplished this goal only by employing an openended, meaningless standard for causation.

McBride, 131 S. Ct. at 2651 (Roberts, C.J., dissenting).

198. See W. Jonathan Cardi, Reconstructing Foreseeability, 46 B.C. L. REv. 921, 925-28 (2005). For a court guilty of just such a doctrinal collapse, see Moody v. Bos. \& Me Corp., 921 F.2d 1, 2-5 (1st Cir. 1990). For a commentator making the same error, see Hovenkamp, supra note 27 , at $22-25$.

199. The dissent assumed that the "any part, even the slightest" language adopted a but-for standard and then went on to criticize it for neglecting a scope of liability component. 